\title{
Intelligent Coordination of Overcurrent and Distance Relays using Meta Heuristic Algorithms
}

\author{
Saptarshi ROY ${ }^{1}$, Suresh Babu PERLI ${ }^{2}$, and N V Phanendra Babu ${ }^{3}$ \\ ${ }^{1,3}$ Research Scholar, Dept., of Electrical Engineering, NIT Warangal, INDIA \\ ${ }^{2}$ Assistant Professor, Dept., of Electrical Engineering, NIT Warangal, INDIA \\ saptarshi.roy.ju@gmail.com ${ }^{1}$,phanendra229@gmail.com ${ }^{3}$ and drsureshperli@nitw.ac.in²
}

\begin{abstract}
Relay coordination is very important from the point of view of security and healthy operation of power system. Relays should be organized in such a way that every relay should have at least one back up relay and coordination time interval between primary and secondary relays should be maintained. This paper presents the solution of relay coordination problem using Teaching learning based optimization technique (TLBO) by utilizing an IEEE 5 bus and IEEE 30 bus test system. The obtained results are compared with the results obtained from other contemporary meta-heuristic techniques like Genetic Algorithm (GA) and Particle Swarm Optimization technique (PSO). It is observed that TLBO is the best among those with respect to process speed. After this we have done an extension of the work by introducing critical element and network graph theory based relay minimization technique. It is expected that this analysis will be helpful to maintain the network reliability and healthy flow of power.
\end{abstract}

Index Terms: Relay co-ordination, Teaching Learning based optimization, Overcurrent relay characteristics, Main backup relay pairs, minimization of the relays.

\section{Introduction}

Relay Co-ordination is necessary from the point of view of reliability and security of power system. Proper relay co-ordination ensures smooth and secured operation of power system. Relay co-ordination ensures minimum system disruption and continuing operation of healthy part of the circuit during operation. Thus, it is very important for protection system design. In a nutshell a protection system should be designed as follows:

Every section of the protection system will be protected by a pair of main relay and back up relay at least. A main relay is meant for the clearance of the fault. In case of failure of main relay, back up relay will take care after providing sufficient time discrimination. In some cases more than one backup relay is provided for better protection reliability of the system. The relay coordination problem is having several constraints. e.g- Proper co-ordination time interval (CTI) should be maintained between the main and backup relay pairs, proper intelligent relay characteristics should be chosen in case of digital relays; proper pick up current constraints, Time setting multiplier (TSM) constraints, constraints on relay operating time and constraints on plug setting multiplier ( PSM) are to be satisfied. So, relay co-ordination problem is nothing but highly constraint problem. Heuristic and meta heuristic techniques are often applied to obtain optimal solution for this kind of problem. In this paper Teaching learning based optimization ( TLBO) is used to solve this problem on an IEEE 5 bus and IEEE 30 bus test system. Proper desirable TSM values, optimum operation time of relays are calculated and proper intelligent characteristics of relays are also selected.

From the study of literatures about co-ordination of relays, it is found that, relay co-ordination is first implemented on over current relays. Initially it was done by using various types of linear programming techniques. e.g- Simplex , two phase simplex and dual simplex methods [1]-[4]. But there are some problems associated with this techniques. Most eminent problem regarding this techniques is no solution is available unless all the constraints regarding this problem are satisfied. So, people gradually move towards the intelligent and meta-heuristic techniques for solution of this problem. Advantage of using these techniques is they give optimal dynamic 
solutions, instead of exact solutions, by optimally satisfying all the constraints. This feature is very useful for smooth operation and control of power network.

Instead of using only over current relays, over current and distance relays used in pairs is found to be more effective, as they have directional property as well as fault sensing capability. So, now a days over current and distance relays are often used in pairs in any transmission system. To achieve better co-ordination, a distance relay with a distance relay, an over current relay with an over current relay and an over current relay with a distance relay must be properly coordinated. One will act as main relay and another one as back up. Proper co-ordination time interval should be maintained between them. Time discrimination values also should be minimized. In ref. [5], optimal co-ordination is done by Genetic Algorithm. Ref. [6] shows optimal co-ordination by using Particle swarm optimization and Ref. [7] shows the time coordination by using evolutionary algorithm. But all these types of schemes having several lacuna:

1. Mis-coordination problem: Which leads to error is relay co-ordination as well as increased time discrimination values.

2. Lack of solution for relays with discrete and continuous time setting multipliers (TSMs).

The problems are resolved [8] with the addition of a new expression with the objective function. All the methodologies discussed above are based on over current relay characteristics and the fixed relay characteristics. But in digital relays, several intelligent over current relay characteristics are existing which remain unutilized in the previous works. So, an algorithm is required which can select the best fitting characteristics among different available intelligent relay characteristics of digital relays during relay co-ordination will be more effective and accurate. Ref. [9] shows relay co-ordination with a hybrid GA algorithm which is helpful in relay co-ordination of over current and distance relays. Ref. [10] demonstrates, a relay co-ordination technique using GA and intelligent relay characteristics selection. Ref. [11]-[13] shows relay coordination using TLBO for small systems but all of them used fixed characteristics (Standard IDMT). None of them used different intelligent characteristics available in digital relays.

We have considered all these loopholes of previous works in our present work and tried to overcome it by our technique. In this paper, we have used Teaching learning based optimization (TLBO) for distance and over current relay co-ordination with intelligent over current relay characteristics selection. Distance and over current relays are used as pairs to protect transmission lines. Relay co-ordination using TLBO and with intelligent over current relay characteristics is a novel contribution in this paper. The method is more simple and reliable than previous methods used. We have used a 5 bus system and IEEE 30bus system to demonstrate the effectiveness of our work. Further we have extended our work considering the minimization of relays for relay coordination. The obtained results seem to be in order and satisfactory.

\section{Teaching Learning Based Optimization (TLBO)}

TLBO is an algorithm inspired by teaching learning process. It is proposed by Rao et al. [14]. The learning process will be done through two stages such as teacher stage and learner stage. While modelling the algorithm, the group of learners was modelled as population; subjects opted by learners were modelled as design variables. Here, learners result becomes the fitness value. After iteration, the best solution inside the population becomes the teacher. And, the constraints of optimization problem become design variables [15]-[18].

\section{A. Teacher Stage}

The teacher stage is the first stage of this algorithm. As all of us know teacher teaches students and increases or improves the mean of their result depending upon their capability. Suppose that there are ' $a$ ' number of subjects or design variables and ' $b$ ' number of learners exist. The mean result of the learners is $m_{c, d}$ in a particular subject ' $c$ '. The best overall result considering all the subjects together obtained in the entire population of learners can be considered the result of the best learner, Kbest. The best learner will be considered as teacher. The difference between the existing mean result of each subject and the teacher for each subject is given by Eq.(1) 


$$
\text { difference_mean } c, k, d=r_{d}\left(x_{c, \text { Kbest }, d}{ }^{-t} m_{c, d}\right) \quad \mathrm{k}=1 \text { to } \mathrm{b}
$$

Where $x_{c}, K_{b e s t, d}$, is the result of the best learner (i.e. teacher) in subject c. $t_{\mathrm{f}}$ is the teaching factor and $r_{d}$ is the random number in the range $[0,1]$. The value of $t_{f}$ can be either 1 or 2 . The value of $\mathrm{t}_{\mathrm{f}}$ is decided randomly with equal probability as follows:

$t_{f}=\operatorname{round}[1+\operatorname{rand}(0,1)\{2-1\}]$

The value of $t_{f}$ is randomly decided by the algorithm using Eq. (2). Based on the difference_mean ${ }_{c, K, d}$, the existing solution is updated in the teacher phase according to the following expression (ref. Eq. (3)):

$$
x_{c, K, d}^{\prime}=x_{c, K, d}+\text { difference_mean }, K, d
$$

$\mathrm{x}_{c, K, d}^{\prime}$ is the new value of $x_{c, K, d} . x_{c, K, d}^{\prime}$ should be accepted if it improves the value of the function. After teacher stage, all fitted values will be given as input to the learner stage. So, it means the learner stage depends on teacher stage.

\section{A. Learner Stage}

The second part of the algorithm is Learner phase. Learners boost up their knowledge by interactions among themselves. Consider a population size of ' $b$ ', the learning phenomenon of this phase can be expressed below.

Randomly select two learners $e$ and f such that $x_{\text {total-e, } d}^{\prime} \neq x_{\text {total- } f, d}^{\prime}$ (where, $\mathrm{x}_{\text {total-e, } d}^{\prime}$ and $x_{\text {total- }, d, d}^{\prime}$ are the updated values of $x_{\text {total-e, } d}$ and $x_{\text {total-f, } d}$ respectively at the end of teacher phase)(ref. Eq. (4) and Eq. (5)):

$$
\begin{aligned}
& x_{c, e, d}^{\prime \prime}=x_{c, e, d}^{\prime}+r_{d}\left(x_{c, e, d}^{\prime}-x_{c, e, d}^{\prime}\right), \text { if } x_{t o t a l-e, d}^{\prime}<x_{t o t a l-f, d}^{\prime} \\
& x_{c, e, d}^{\prime \prime}=x_{c, e, d}^{\prime}+r_{d}\left(x_{c, f, d}^{\prime}-x_{c, e, d}^{\prime}\right), \text { if } x_{t o t a l-e, d}^{\prime}>x_{t o t a l-f, d}^{\prime}
\end{aligned}
$$

Accept $x_{c, e, d}^{\prime \prime}$ if it gives a better function value. Figure 1 shows the flowchart of TLBO algorithm.

\section{Problem Statement}

For better protection arrangements, it is common to use both distance and over current relays as main and back up relays respectively, in power transmission protection schemes [19]-[23]. For making optimal co-ordination of distance and over current relays we choose a fitness function same as Eq. (6). All the parameters used in this fitness function are described below (ref. Eq. (7), Eq. (8) and Eq. (9)):

$$
\begin{aligned}
& \text { Fitnessfunction }=\min \left(\alpha \sum_{i=1}^{n} t_{i}+\beta \sum_{i=1}^{n}\left|T_{D I O C i}-\right| T_{D I O C}||+\right. \\
& \left.\lambda \sum_{i=1}^{n}\left|T_{O C D I i}-\right| T_{O C D I}||+\delta \sum_{i=1}^{n}\left|T_{O C i}-\right| T_{O C}||\right)
\end{aligned}
$$

Where

$$
\begin{aligned}
& T_{O C i}=T_{\text {Ocbackupi }}-T_{\text {Ocmaini }}-C^{\prime} \\
& T_{D I O C i}=T_{O c i}-T_{z 2 i}-C T I^{\prime} \\
& T_{O C D I i}=T_{z 2 i}-T_{O C i}-C T I^{\prime}
\end{aligned}
$$

$\mathrm{T}_{\mathrm{oc}}$ is the operating time of over current relay and $\mathrm{T}_{\mathrm{z} 2}$ is the operating time of $2 \mathrm{nd}$ zone of distance relay. $\alpha, \beta, \lambda, \delta$ are penalty factors.

\section{Constraints}

The several constraints need to be satisfied to obtain optimal co-ordination.

\section{A. Co-ordination constraints}

The co-ordination constraints are described by Eq. (10) and Eq. (11): 
Saptarshi ROY, et al.

$$
\begin{aligned}
& T_{z 2 \text { backup }}-T_{\text {ocmain }} \geq C T I \\
& T_{\text {ocbackup }}-T_{z 2 \text { main }} \geq C T I
\end{aligned}
$$

CTI is coordination time interval whose typical value is between $0.2-0.3$ secs.

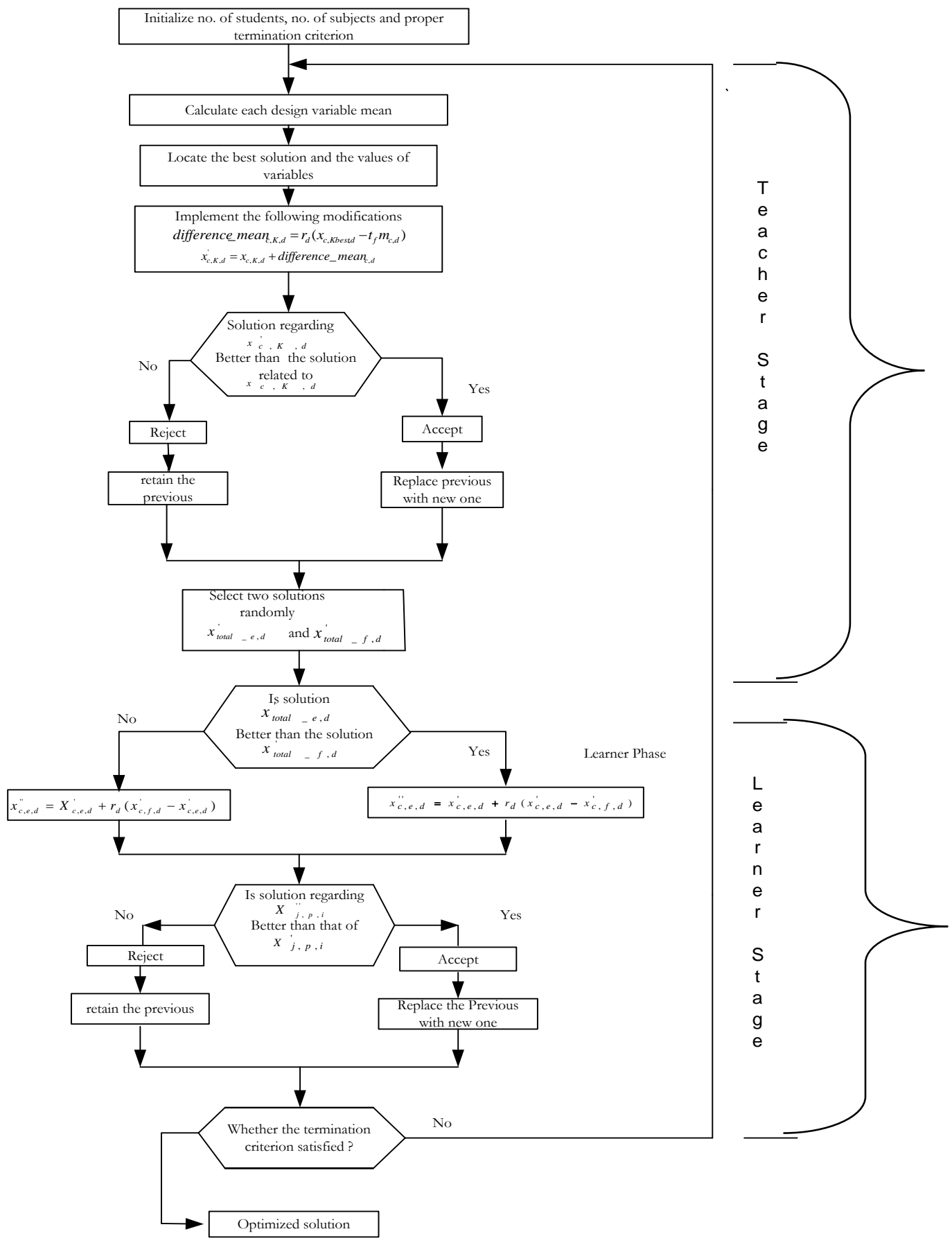

Yes

Figure 1. Flowchart of TLBO algorithm 


\section{B. Relay Characteristics}

The over current relay characteristics are typically of below nature (ref. Eq. (12)):

$$
t=\operatorname{TSM}\left(\frac{K}{M^{\alpha}-1}+L\right)
$$

$t=$ time of operation of the relay.

$T S M=$ Time setting multiplier.

$K, L$ and $\alpha$ are the constants. It varies characteristics to characteristics.

$M$ is the ratio between short circuit current Isc and pick up current $I p$.

TSM is supposed to be continuous and can take any value between 0.05-1.1. Co-ordinating time interval in each cases is supposed to be $0.25 \mathrm{sec}$. Table 1 and Figure 2 shows 8 types of intelligent characteristics available in digital over current relay with different parameter values.

Table 1. Characteristics of over current relay

\begin{tabular}{|c|c|c|c|c|c|}
\hline $\begin{array}{l}\text { No. of } \\
\text { the } \\
\text { characte } \\
\text { ristic }\end{array}$ & $\begin{array}{l}\text { Name of the } \\
\text { characteristic }\end{array}$ & $\begin{array}{l}\text { Standard } \\
\text { followed }\end{array}$ & $K$ Value & $\alpha$ Value & $L$ Value \\
\hline & $\begin{array}{l}\text { Short time } \\
\text { inverse }\end{array}$ & AREVA & 0.05 & 0.04 & 0 \\
\hline & $\begin{array}{l}\text { Standard } \\
\text { inverse }\end{array}$ & IEC & 0.14 & 0.02 & 0 \\
\hline & Very inverse & IEC & 13.5 & 1 & 0 \\
\hline & $\begin{array}{l}\text { Extremely } \\
\text { inverse }\end{array}$ & IEC & 80 & 2 & 0 \\
\hline & $\begin{array}{l}\text { Long time } \\
\text { inverse }\end{array}$ & AREVA & 120 & 1 & 0 \\
\hline & $\begin{array}{l}\text { Moderately } \\
\text { inverse }\end{array}$ & $\begin{array}{l}\text { ANSI/ } \\
\text { IEEE }\end{array}$ & 0.0515 & 0.02 & 0.114 \\
\hline & Very inverse & $\begin{array}{l}\text { ANSI/ } \\
\text { IEEE }\end{array}$ & 19.61 & 2 & 0.491 \\
\hline & $\begin{array}{l}\text { Extremely } \\
\text { inverse }\end{array}$ & $\begin{array}{l}\text { ANSI/ } \\
\text { IEEE }\end{array}$ & 28.2 & 2 & 0.1217 \\
\hline
\end{tabular}

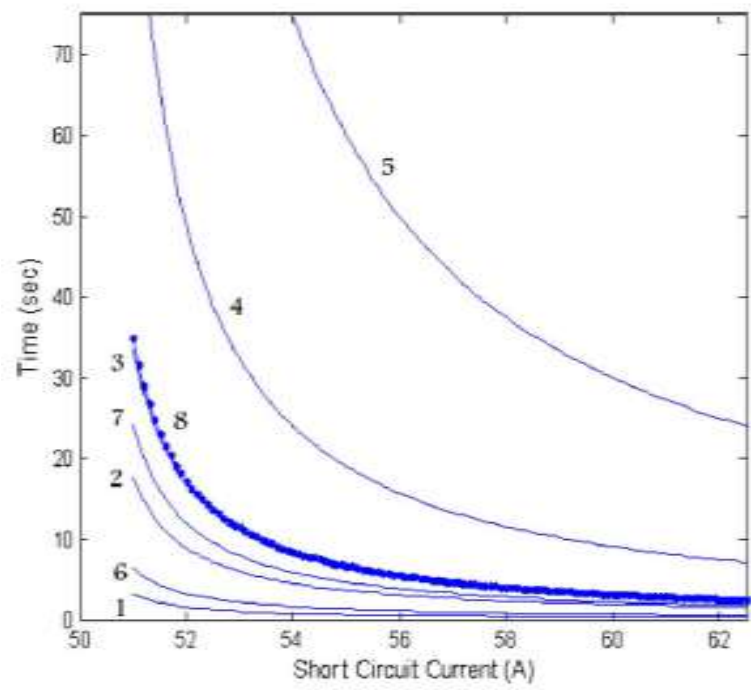

No. 1- Short Tme Invers

2-Standard Inverse

3-Very Inverse

4-Extremely Inverse

5- Long Time Inverse

6-Moderately Inverse

7. Very Inverse

8- Estremely Inverse

Figure 2. Intelligent overcurrent relay characteristics diagram 


\section{Pick-up current constraints}

Pick up current is having a limit. The value of pick up current is very important for the relay co-ordination problem. To sense a very little amount of fault current the pickup current should be less than minimum fault current. On the other hand the minimum pick up current may be doubled under small overloaded condition to avoid any mal-operation. The limits of pick up current can be expressed as Eq. (13) below [13].

$$
I p_{\min } \leq I p \leq I p_{\max }
$$

\section{TSM constraints}

TSM is supposed to be continuous and can take any value between 0.05-1.1. Mathematically it can be expressed as below (ref. Eq. (14)).

$$
T S M_{\min } \leq T S M \leq T S M_{\max }
$$

\section{E. Constraints on relay operating time}

For minimizing or mitigating mal-operation due to transient, overshoot or any other critical condition of the network, relays should operate after a minimum time. Limits on time of operation of relay $\left(\mathrm{t}_{\mathrm{op}}\right)$ can be expressed as (ref. Eq. (15)).

$$
t_{o p \min } \leq t_{o p} \leq t_{o p \max }
$$

Minimum operation time of relay is $0.1 \mathrm{sec}$ and maximum depends on the requirement of the user.

\section{F. Constraints on PSM:}

Plug setting multiplier (PSM) should be within range. Mathematically it can be expressed as follows (ref. Eq. (16)).

$$
P S M_{\min } \leq P S M \leq P S M_{\max }
$$

\section{Test Results}

The methodology is tested on a IEEE 5 Bus system and IEEE 30 bus system. The results are listed in subsections 5.1 and 5.2.

\section{A. Results of IEEE 5 Bus System}

The proposed methodology has been implemented here using IEEE 5 Bus Test system. Test system data is obtained from Ref. [24]. The relay arrangement for the above mentioned power system is shown in Figure 3. The directional mho relays are used here. Over current relays are arranged using time graded protection scheme with IDMT (Inverse definite minimum time) characteristics. Different types of over current relay characteristics available in digital relays are obtained from Ref.[10].

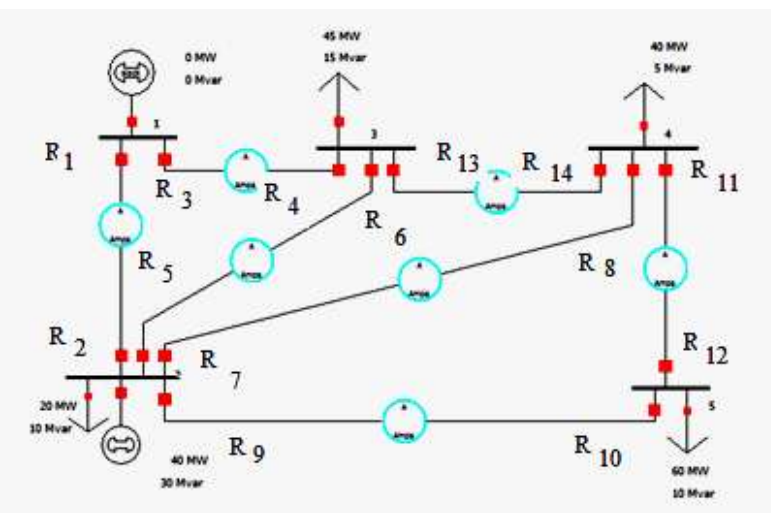

Figure 3. Relay arrangement for IEEE-5 Bus System 
The main and back up relay pairs for the above IEEE 5 Bus system are shown in Table 2.

Table 2. Main and backup relay pairs

\begin{tabular}{|c|c|c|c|c|c|}
\hline $\begin{array}{c}\text { Sl. } \\
\text { No. }\end{array}$ & $\begin{array}{c}\text { Main over } \\
\text { current and } \\
\text { distance relays }\end{array}$ & $\begin{array}{c}\text { Back up over } \\
\text { current and } \\
\text { distance } \\
\text { relays }\end{array}$ & $\begin{array}{c}\text { Sl. } \\
\text { No. }\end{array}$ & $\begin{array}{c}\text { Main over } \\
\text { current and } \\
\text { distance } \\
\text { relays }\end{array}$ & $\begin{array}{c}\text { Back up over } \\
\text { current and } \\
\text { distance } \\
\text { relays }\end{array}$ \\
\hline 1. & $\mathrm{R}_{1}$ & $\mathrm{R}_{4}$ & 9. & $\mathrm{R}_{9}$ & $\mathrm{R}_{1}$ \\
\hline 2. & $\mathrm{R}_{2}$ & $\mathrm{R}_{10}$ & 10. & $\mathrm{R}_{10}$ & $\mathrm{R}_{11}$ \\
\hline 3. & $\mathrm{R}_{3}$ & $\mathrm{R}_{2}$ & 11. & $\mathrm{R}_{11}$ & $\mathrm{R}_{13}$ \\
\hline 4. & $\mathrm{R}_{4}$ & $\mathrm{R}_{14}$ & 12. & $\mathrm{R}_{12}$ & $\mathrm{R}_{9}$ \\
\hline 5. & $\mathrm{R}_{5}$ & $\mathrm{R}_{8}$ & 13. & $\mathrm{R}_{13}$ & $\mathrm{R}_{3}$ \\
\hline 6. & $\mathrm{R}_{6}$ & $\mathrm{R}_{14}$ & 14. & $\mathrm{R}_{13}$ & $\mathrm{R}_{5}$ \\
\hline 7. & $\mathrm{R}_{7}$ & $\mathrm{R}_{6}$ & 15. & $\mathrm{R}_{14}$ & $\mathrm{R}_{7}$ \\
\hline 8. & $\mathrm{R}_{8}$ & $\mathrm{R}_{13}$ & 16. & $\mathrm{R}_{14}$ & $\mathrm{R}_{12}$ \\
\hline
\end{tabular}

The typical operating time of first, second and third zones of all distance relays are $20 \mathrm{~ms}$, $0.3 \mathrm{sec}$ (or more) and $0.6 \mathrm{sec}$ (or more). The short circuit currents data of the main and back up over current relays must be calculated from close-in bus fault cases (Critical fault locations). The information regarding pick up current settings are given in Table 3. The value of pick up current of each over current relay is assumed approximately to be 1.25 times of the relevant maximum load in approximated integer form. The short circuit current data are shown in Table 4. From Table-2, it is found that relay no. 13 and 14 are having better protection reliability as both of them have two back up relays.

Table 3. Pickup current values of the Relay

\begin{tabular}{|c|c|c|}
\hline $\begin{array}{c}\text { Relay } \\
\text { number }\left(\mathrm{R}_{\mathrm{i}}\right)\end{array}$ & $\begin{array}{c}\text { Load } \\
\text { Current(amps) }\end{array}$ & $\begin{array}{c}\text { Pick up } \\
\text { Current(amps) }\end{array}$ \\
\hline 1 & 386 & 483 \\
\hline 2 & 383 & 479 \\
\hline 3 & 177 & 221 \\
\hline 4 & 177 & 221 \\
\hline 5 & 90 & 113 \\
\hline 6 & 93 & 116 \\
\hline 7 & 132 & 165 \\
\hline 8 & 160 & 200 \\
\hline 9 & 240 & 300 \\
\hline 10 & 242 & 303 \\
\hline 11 & 24 & 30 \\
\hline 12 & 22 & 28 \\
\hline 13 & 72 & 90 \\
\hline 14 & 70 & 88 \\
\hline
\end{tabular}


Table 4. Short Circuit Current data for main and back up relays

\begin{tabular}{|c|c|c|c|}
\hline $\begin{array}{c}\text { Main } \\
\text { Relay }\left(\mathrm{R}_{\mathrm{i}}\right)\end{array}$ & $\begin{array}{c}\text { Back up } \\
\text { Relay }\left(\mathrm{R}_{\mathrm{i}}\right)\end{array}$ & $\begin{array}{c}\text { Main relay short } \\
\text { circuit current } \\
(\mathrm{amps})\end{array}$ & $\begin{array}{c}\text { Back up relay short } \\
\text { circuit current(amps) }\end{array}$ \\
\hline 1 & 4 & 684 & 97 \\
\hline 2 & 10 & 790 & 18 \\
\hline 3 & 2 & 1060 & 561 \\
\hline 4 & 14 & 721 & 443 \\
\hline 5 & 8 & 1151 & 34 \\
\hline 6 & 14 & 761 & 443 \\
\hline 7 & 6 & 1151 & 31 \\
\hline 8 & 13 & 661 & 581 \\
\hline 9 & 1 & 1176 & 272 \\
\hline 10 & 11 & 374 & 481 \\
\hline 11 & 13 & 858 & 708 \\
\hline 12 & 9 & 709 & 326 \\
\hline 13 & 3 & 602 & 280 \\
\hline 13 & 5 & 602 & 377 \\
\hline 14 & 7 & 561 & 184 \\
\hline 14 & 12 & 561 & \\
\hline
\end{tabular}

The objective function is found on the basis of trial and error. Ultimately the objective of choosing objective function is to reduce the time of operation of relay, same as in the case of over current to over current relay co-ordination case. The only difference here is some additional expressions are appearing due to the presence of distance relay. When $\left|T_{D I O C i}\right|$ is positive then the second term of objective function is becoming zero but when $\left|T_{D I O C i}\right|$ is negative then the second term is additive with the objective function and increasing its value. Since it is a minimization problem, the chance of survival of such fitness value is mitigated by this approach. As per coordination constraints $\left|T_{D I O C i}\right|$ value should be always greater than equals to zero. Its value can be negative only in case of mis-co-ordination. So, with such approach the chance of mis-coordination problem is almost nullified. The same kind of explanation can be given for choosing the third and fourth term of the fitness function also.

Critical fault location-There is a minimum length of the line, below which the relay is unable to protect the line. If the fault point is too close to the relaying point, the relay may fail to operate. The relay will operate if the following condition is satisfied:

$\left(\Delta \Phi_{k}\right)$

$\mathrm{Z}_{\mathrm{S}}$ is the source impedance behind the relay, $\mathrm{Z}_{\mathrm{L}}$ is the line impedance from the relaying point to the fault point, $\mathrm{E}$ is the line input voltage ( or normal secondary C.T voltage), $\mathrm{V}$ is the voltage at relay location. Critical fault location is that point, which is the minimum distance of the line to make the relay to start work. In that point the following condition is satisfied:

$$
\Delta P_{l k}=(0.2-0.26) \text { p.u }
$$

In critical fault location, the discrimination time is zero i.e

$$
\Phi_{k}=0.39 p . u
$$

Usually the critical fault location is situated within $12 \%$ length of each transmission line [37]. 
Table 5. Output Table (IEEE 5-bus system)

\begin{tabular}{|c|c|c|c|}
\hline $\begin{array}{c}\text { Relay } \\
\left(\mathrm{R}_{\mathrm{i}}\right)\end{array}$ & $\begin{array}{c}\text { Second Zone } \\
\text { operation time } \\
\left(\mathrm{T}_{\mathrm{z} 2}\right)(\mathrm{sec})\end{array}$ & $\mathrm{TSM}$ & $\begin{array}{c}\text { No. of selected } \\
\text { Characteristic } \\
\text { from Table1 }\end{array}$ \\
\hline 1 & 0.9997 & 0.05 & 7 \\
\hline 2 & 0.5946 & 0.05 & 7 \\
\hline 3 & 0.3503 & 0.0985 & 3 \\
\hline 4 & 0.4724 & 0.08073 & 2 \\
\hline 5 & 0.4327 & 0.1467 & 2 \\
\hline 6 & 0.3465 & 0.0949 & 2 \\
\hline 7 & 0.3102 & 0.1373 & 3 \\
\hline 8 & 0.3668 & 0.0634 & 2 \\
\hline 9 & 0.3454 & 0.0747 & 3 \\
\hline 10 & 0.2956 & 0.05 & 1 \\
\hline 11 & 0.3640 & 0.1803 & 2 \\
\hline 12 & 0.4855 & 0.2314 & 2 \\
\hline 13 & 0.3218 & 0.1356 & 3 \\
\hline 14 & 0.2628 & 0.10465 & 3 \\
\hline $\begin{array}{c}\text { Average } \\
\text { Value }\end{array}$ & 0.42488 & 0.107013 & - \\
\hline $\begin{array}{c}\text { Fitness } \\
\text { value }\end{array}$ & 100 & - & - \\
\hline
\end{tabular}

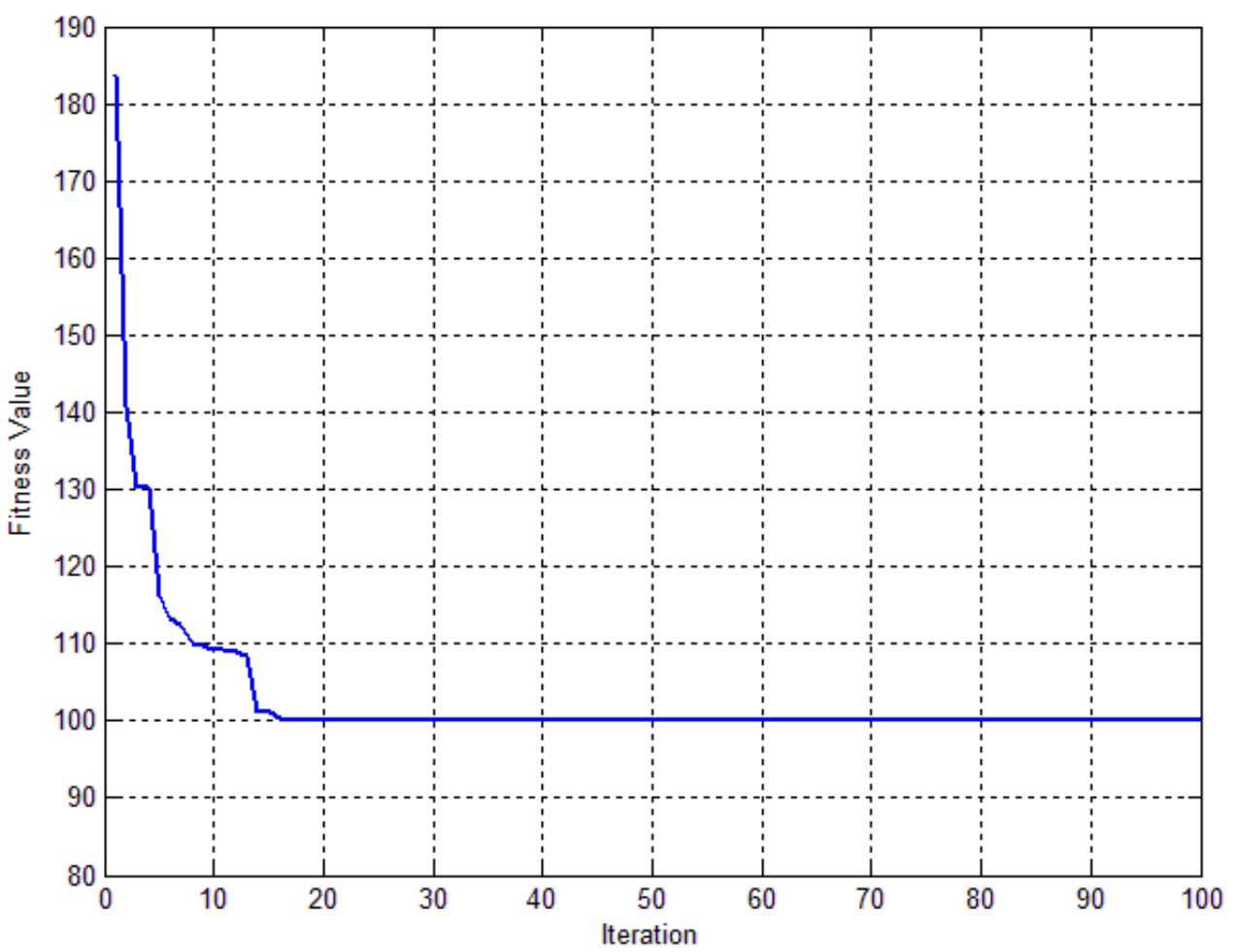

Figure 4. Convergence characteristics of the TLBO algorithm for IEEE 5 bus system 
The output results are obtained by applying the TLBO (Teaching learning based optimization) for a network shown in Figure 3. TSMs and over current relay characteristics selected by TLBO are shown in Table 5. TSMs are assumed as continuous (0.05-1.1) in all the cases. The time of operation of relays in each case are also shown in the Table 4 . The various outputs for IEEE 5 bus test system are shown pictorially from Figure 4 to Figure 8.

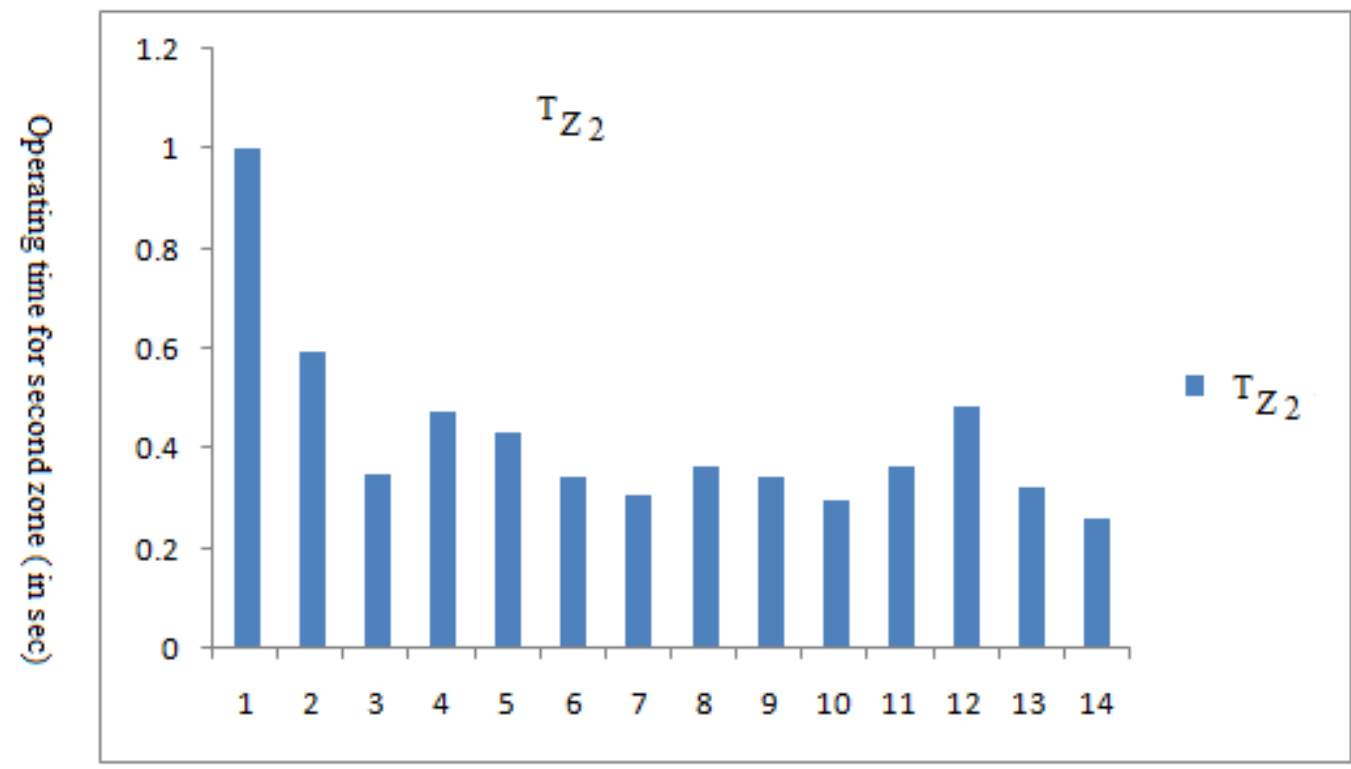

Relay number

Figure 5. Comparison of operating time of second zone of relays for IEEE 5 bus system

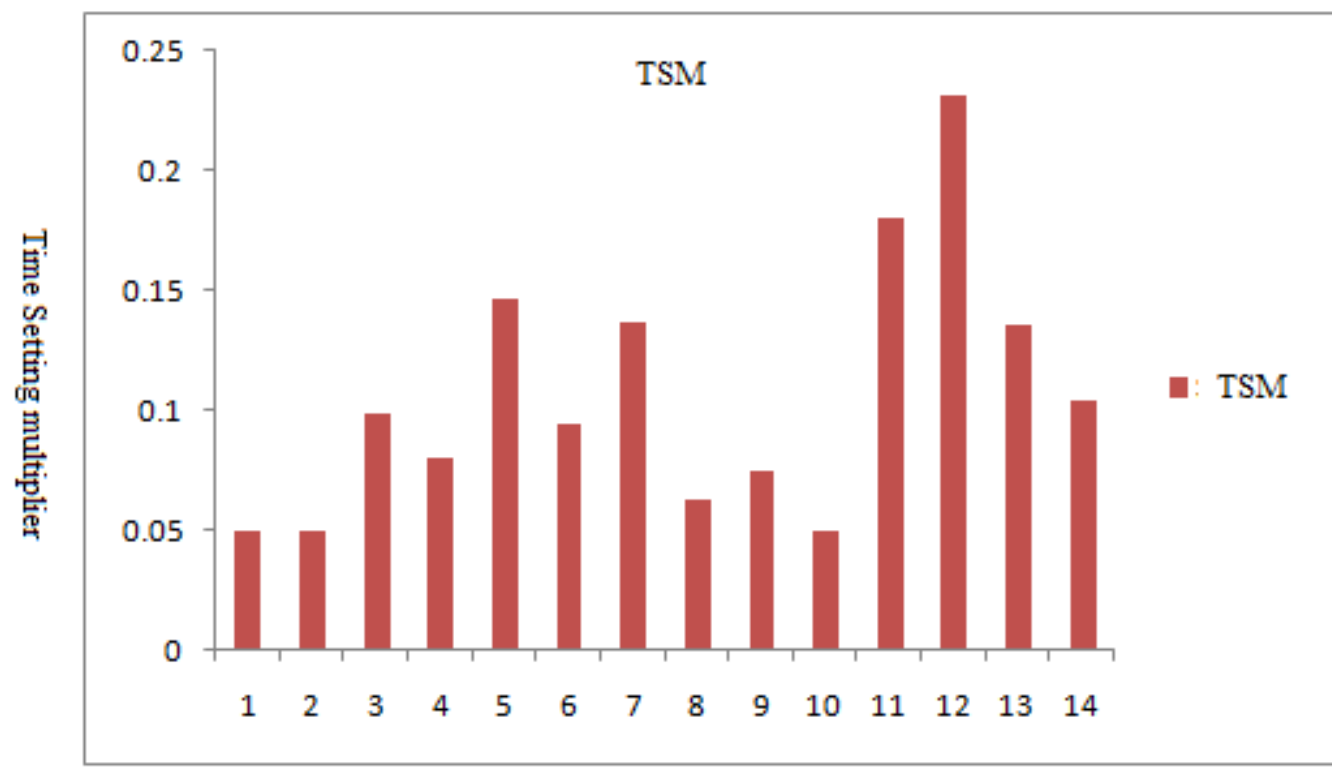

Relay numbers

Figure 6. Comparison of optimum Time setting multipliers of relays for IEEE 5 bus system 


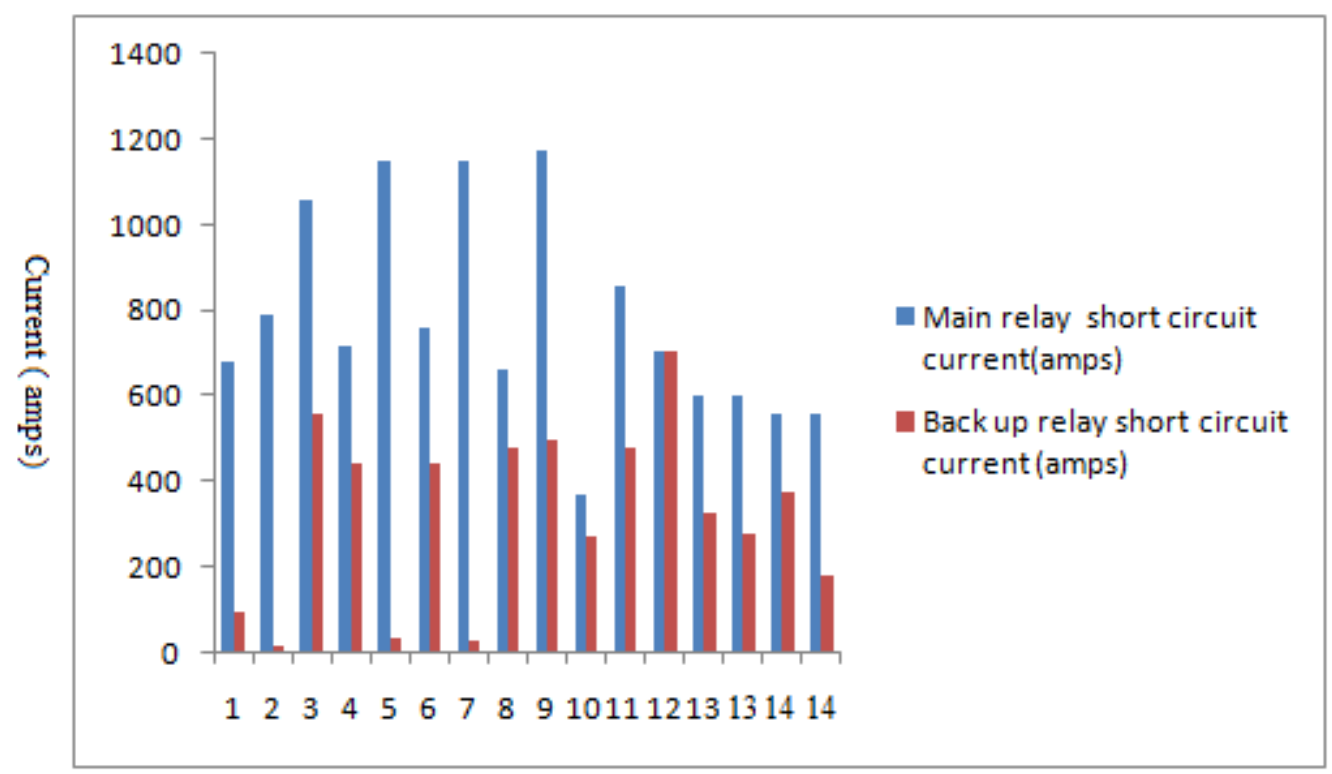

\section{Relay numbers}

Figure 7. Comparison of short circuit currents of main and backup relays for IEEE 5 bus system

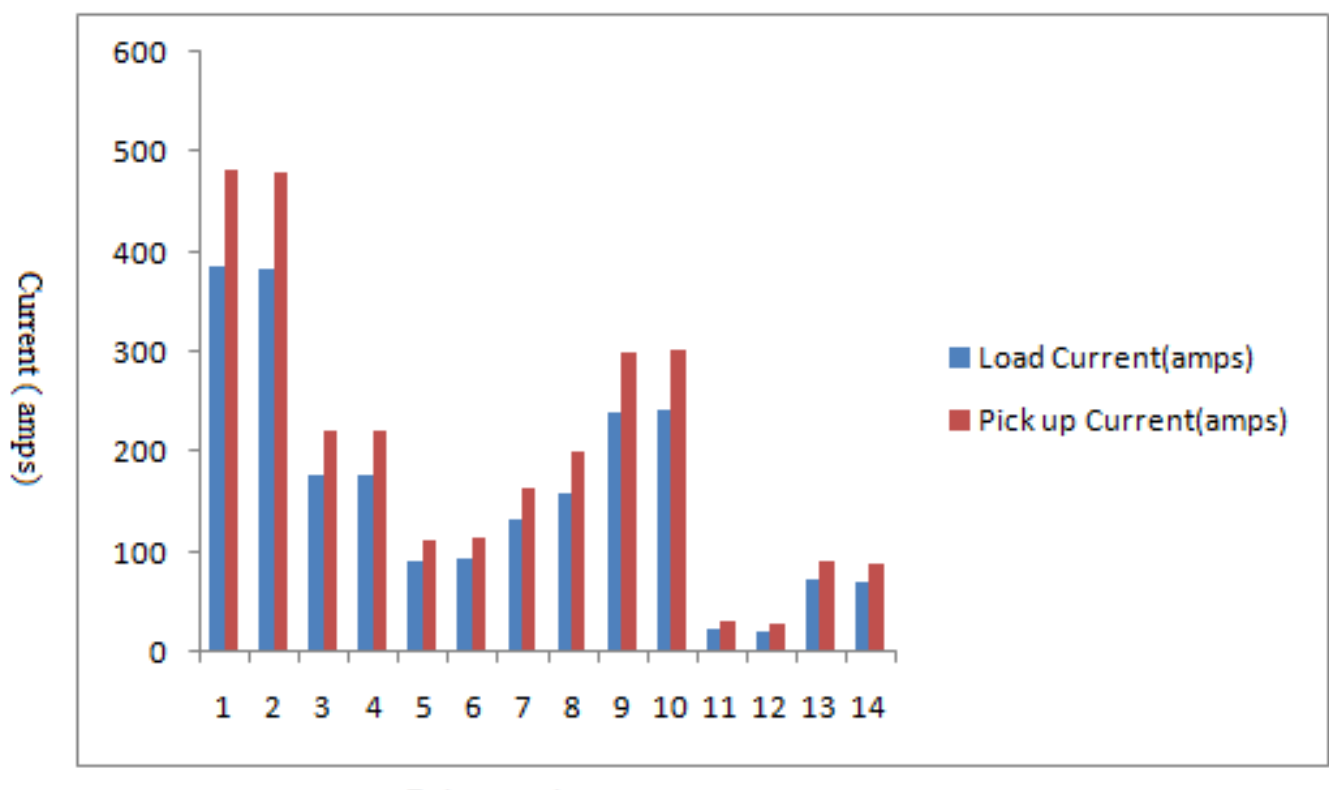

\section{Relay numbers}

Figure 8. Comparison of Load currents and pick up currents of various relays for IEEE 5- bus system

\section{B. Results of IEEE 30 Bus System}

To test the methodology, an IEEE 30 Bus system has been selected. Test system data are obtained from Ref. [25]. The relay arrangements are shown for this power system as per Table 6. The mho directional relays are used here. Over current relays are arranged using time graded protection scheme with IDMT (Inverse definite minimum time) characteristics. 
Saptarshi ROY, et al.

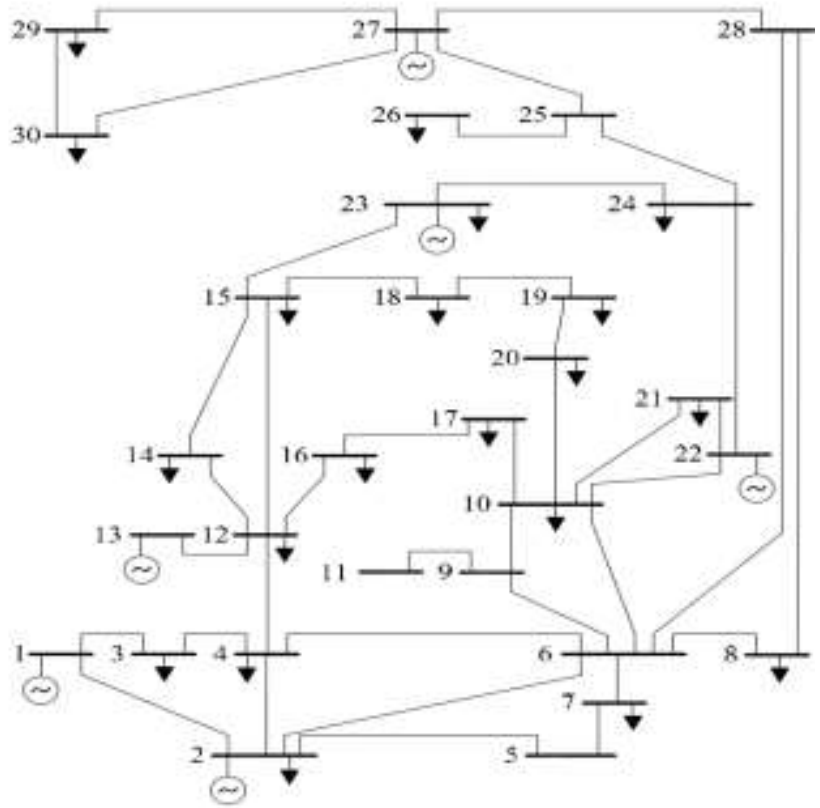

Figure 9. IEEE-30 Bus System

Table 6. Relay arrangement for IEEE 30 bus system

\begin{tabular}{|c|c|c|c|c|}
\hline S1. No. & $\begin{array}{c}\text { Branch data from } \\
\text { bus } \\
\text { no. }\end{array}$ & $\begin{array}{c}\text { Branch data } \\
\text { to bus } \\
\text { no. }\end{array}$ & $\begin{array}{c}\text { Relay no. }\left(\mathrm{R}_{\mathrm{i}}\right) \\
\text { adjacent to } \\
\text { from bus }\end{array}$ & $\begin{array}{l}\text { Relay no. }\left(\mathrm{R}_{\mathrm{i}}\right) \\
\text { adjacent to } \\
\text { to bus }\end{array}$ \\
\hline 1 & 1 & 2 & 1 & 2 \\
\hline 2 & 1 & 3 & 3 & 4 \\
\hline 3 & 2 & 4 & 5 & 6 \\
\hline 4 & 3 & 4 & 7 & 8 \\
\hline 5 & 2 & 5 & 9 & 10 \\
\hline 6 & 2 & 6 & 11 & 12 \\
\hline 7 & 4 & 6 & 13 & 14 \\
\hline 8 & 5 & 7 & 15 & 16 \\
\hline 9 & 6 & 7 & 17 & 18 \\
\hline 10 & 6 & 8 & 19 & 20 \\
\hline 11 & 6 & 9 & - & - \\
\hline 12 & 6 & 10 & - & - \\
\hline 13 & 9 & 11 & - & - \\
\hline 14 & 9 & 10 & - & - \\
\hline 15 & 4 & 12 & - & - \\
\hline 16 & 12 & 13 & - & - \\
\hline 17. & 12 & 14 & 21 & 22 \\
\hline 18. & 12 & 15 & 23 & 24 \\
\hline 19. & 12 & 16 & 25 & 26 \\
\hline 20. & 14 & 15 & 27 & 28 \\
\hline 21. & 16 & 17 & 29 & 30 \\
\hline 22. & 15 & 18 & 31 & 32 \\
\hline
\end{tabular}




\begin{tabular}{|c|c|c|c|c|}
\hline Sl. No. & $\begin{array}{l}\text { Branch data } \\
\text { from bus no. }\end{array}$ & $\begin{array}{l}\text { Branch data } \\
\text { to bus no. }\end{array}$ & $\begin{array}{c}\text { Relay no. }\left(\mathrm{R}_{\mathrm{i}}\right) \\
\text { adjacent to } \\
\text { from bus }\end{array}$ & $\begin{array}{c}\text { Relay no. }\left(\mathrm{R}_{\mathrm{i}}\right) \\
\text { adjacent to } \\
\text { to bus }\end{array}$ \\
\hline 23 & 18 & 19 & 33 & 34 \\
\hline 24. & 19 & 20 & 35 & 36 \\
\hline 25. & 10 & 20 & 37 & 38 \\
\hline 26. & 10 & 17 & 39 & 40 \\
\hline 27. & 10 & 21 & 41 & 42 \\
\hline 28. & 10 & 22 & 43 & 44 \\
\hline 29. & 21 & 22 & 45 & 46 \\
\hline 30. & 15 & 23 & 47 & 48 \\
\hline 31. & 22 & 24 & 49 & 50 \\
\hline 32. & 23 & 24 & 51 & 52 \\
\hline 33. & 24 & 25 & 53 & 54 \\
\hline 34. & 25 & 26 & 55 & 56 \\
\hline 35. & 25 & 27 & 57 & 58 \\
\hline 36. & 28 & 27 & - & - \\
\hline 37. & 27 & 29 & 59 & 60 \\
\hline 38. & 27 & 30 & 61 & 62 \\
\hline 39. & 29 & 30 & 63 & 64 \\
\hline 40. & 8 & 28 & 65 & 66 \\
\hline 41. & 6 & 28 & 67 & 68 \\
\hline
\end{tabular}

The main and back up relay pairs for IEEE 30 bus system are shown in Table 7

Table 7. Main and backup relay pairs for IEEE 30 bus system

\begin{tabular}{|c|c|c|c|c|c|}
\hline Sl. No. & $\begin{array}{c}\text { Main over } \\
\text { current } \\
\text { (o/c) and } \\
\text { distance } \\
\text { relays }\end{array}$ & $\begin{array}{c}\text { Back up over } \\
\text { current and } \\
\text { distance } \\
\text { relays }\end{array}$ & Sl. No. & $\begin{array}{c}\text { Main over } \\
\text { Current (o/c) } \\
\text { and distance } \\
\text { relays }\end{array}$ & $\begin{array}{c}\text { Back up over (o/c) } \\
\text { and distance relays }\end{array}$ \\
\hline 1 & $\mathrm{R}_{1}$ & $\mathrm{R}_{4}$ & 22 & $\mathrm{R}_{17}$ & $\mathrm{R}_{11}$ \\
\hline 2 & $\mathrm{R}_{2}$ & $\mathrm{R}_{10}$ & 23 & $\mathrm{R}_{18}$ & $\mathrm{R}_{15}$ \\
\hline 3 & $\mathrm{R}_{3}$ & $\mathrm{R}_{2}$ & 24 & $\mathrm{R}_{19}$ & $\mathrm{R}_{68}$ \\
\hline 4 & $\mathrm{R}_{4}$ & $\mathrm{R}_{8}$ & 25 & $\mathrm{R}_{20}$ & $\mathrm{R}_{66}$ \\
\hline 5 & $\mathrm{R}_{5}$ & $\mathrm{R}_{10}$ & 26 & $\mathrm{R}_{21}$ & $\mathrm{R}_{26}$ \\
\hline 6 & $\mathrm{R}_{6}$ & $\mathrm{R}_{14}$ & 27 & $\mathrm{R}_{22}$ & $\mathrm{R}_{28}$ \\
\hline 7 & $\mathrm{R}_{7}$ & $\mathrm{R}_{3}$ & 28 & $\mathrm{R}_{23}$ & $\mathrm{R}_{26}$ \\
\hline 8 & $\mathrm{R}_{8}$ & $\mathrm{R}_{14}$ & 29 & $\mathrm{R}_{24}$ & $\mathrm{R}_{32}$ \\
\hline 9 & $\mathrm{R}_{9}$ & $\mathrm{R}_{1}$ & 30 & $\mathrm{R}_{25}$ & $\mathrm{R}_{22}$ \\
\hline 10 & $\mathrm{R}_{9}$ & $\mathrm{R}_{12}$ & 31 & $\mathrm{R}_{25}$ & $\mathrm{R}_{24}$ \\
\hline 11 & $\mathrm{R}_{9}$ & $\mathrm{R}_{6}$ & 32 & $\mathrm{R}_{26}$ & $\mathrm{R}_{30}$ \\
\hline 12 & $\mathrm{R}_{10}$ & $\mathrm{R}_{16}$ & 33 & $\mathrm{R}_{27}$ & $\mathrm{R}_{21}$ \\
\hline 13 & $\mathrm{R}_{11}$ & $\mathrm{R}_{10}$ & 34 & $\mathrm{R}_{28}$ & $\mathrm{R}_{48}$ \\
\hline 14 & $\mathrm{R}_{12}$ & $\mathrm{R}_{18}$ & 35 & $\mathrm{R}_{29}$ & $\mathrm{R}_{25}$ \\
\hline 15 & $\mathrm{R}_{13}$ & $\mathrm{R}_{7}$ & 36 & $\mathrm{R}_{30}$ & $\mathrm{R}_{39}$ \\
\hline 16 & $\mathrm{R}_{13}$ & $\mathrm{R}_{5}$ & 37 & $\mathrm{R}_{31}$ & $\mathrm{R}_{23}$ \\
\hline 17 & $\mathrm{R}_{14}$ & $\mathrm{R}_{18}$ & 38 & $\mathrm{R}_{32}$ & $\mathrm{R}_{34}$ \\
\hline 18 & $\mathrm{R}_{14}$ & $\mathrm{R}_{11}$ & 39 & $\mathrm{R}_{33}$ & $\mathrm{R}_{31}$ \\
\hline 19. & $\mathrm{R}_{15}$ & $\mathrm{R}_{9}$ & 40 & $\mathrm{R}_{34}$ & $\mathrm{R}_{36}$ \\
\hline 20. & $\mathrm{R}_{16}$ & $\mathrm{R}_{17}$ & 41 & $\mathrm{R}_{35}$ & $\mathrm{R}_{33}$ \\
\hline 21. & $\mathrm{R}_{17}$ & $\mathrm{R}_{13}$ & 42 & $\mathrm{R}_{36}$ & $\mathrm{R}_{37}$ \\
\hline & & & & & \\
\hline
\end{tabular}




\begin{tabular}{|c|c|c|c|c|c|}
\hline S1. No. & $\begin{array}{c}\text { Main over } \\
\text { current (o/c) } \\
\text { and distance } \\
\text { relays }\end{array}$ & $\begin{array}{c}\text { Back up over } \\
\text { current and } \\
\text { distance } \\
\text { relays }\end{array}$ & Sl. No. & $\begin{array}{c}\text { Main over } \\
\text { Current(o/c) and } \\
\text { distance relays }\end{array}$ & $\begin{array}{c}\text { Back up over } \\
\text { (o/c) and } \\
\text { distance } \\
\text { relays }\end{array}$ \\
\hline 43 & $\mathrm{R}_{37}$ & $\mathrm{R}_{40}$ & 62 & $\mathrm{R}_{52}$ & $\mathrm{R}_{49}$ \\
\hline 44 & $\mathrm{R}_{38}$ & $\mathrm{R}_{35}$ & 63 & $\mathrm{R}_{53}$ & $\mathrm{R}_{49}$ \\
\hline 45 & $\mathrm{R}_{39}$ & $\mathrm{R}_{44}$ & 64 & $\mathrm{R}_{54}$ & $\mathrm{R}_{58}$ \\
\hline 46 & $\mathrm{R}_{39}$ & $\mathrm{R}_{38}$ & 65 & $\mathrm{R}_{54}$ & $\mathrm{R}_{56}$ \\
\hline 47 & $\mathrm{R}_{40}$ & $\mathrm{R}_{29}$ & 66 & $\mathrm{R}_{55}$ & $\mathrm{R}_{58}$ \\
\hline 48 & $\mathrm{R}_{41}$ & $\mathrm{R}_{44}$ & 67 & $\mathrm{R}_{56}$ & - \\
\hline 49 & $\mathrm{R}_{42}$ & $\mathrm{R}_{46}$ & 68 & $\mathrm{R}_{57}$ & $\mathrm{R}_{53}$ \\
\hline 50 & $\mathrm{R}_{43}$ & $\mathrm{R}_{40}$ & 69 & $\mathrm{R}_{58}$ & $\mathrm{R}_{62}$ \\
\hline 51 & $\mathrm{R}_{43}$ & $\mathrm{R}_{42}$ & 70 & $\mathrm{R}_{58}$ & $\mathrm{R}_{60}$ \\
\hline 52 & $\mathrm{R}_{44}$ & $\mathrm{R}_{50}$ & 71 & $\mathrm{R}_{59}$ & $\mathrm{R}_{62}$ \\
\hline 53 & $\mathrm{R}_{44}$ & $\mathrm{R}_{45}$ & 72 & $\mathrm{R}_{60}$ & $\mathrm{R}_{64}$ \\
\hline 54 & $\mathrm{R}_{45}$ & $\mathrm{R}_{41}$ & 73 & $\mathrm{R}_{61}$ & $\mathrm{R}_{60}$ \\
\hline 55 & $\mathrm{R}_{46}$ & $\mathrm{R}_{43}$ & 74 & $\mathrm{R}_{62}$ & $\mathrm{R}_{63}$ \\
\hline 56 & $\mathrm{R}_{47}$ & $\mathrm{R}_{27}$ & 75 & $\mathrm{R}_{63}$ & $\mathrm{R}_{59}$ \\
\hline 57 & $\mathrm{R}_{48}$ & $\mathrm{R}_{52}$ & 76 & $\mathrm{R}_{64}$ & $\mathrm{R}_{61}$ \\
\hline 58 & $\mathrm{R}_{49}$ & $\mathrm{R}_{43}$ & 77 & $\mathrm{R}_{65}$ & $\mathrm{R}_{19}$ \\
\hline 59 & $\mathrm{R}_{50}$ & $\mathrm{R}_{54}$ & 78 & $\mathrm{R}_{66}$ & $\mathrm{R}_{67}$ \\
\hline 60 & $\mathrm{R}_{50}$ & $\mathrm{R}_{51}$ & 79 & $\mathrm{R}_{67}$ & $\mathrm{R}_{20}$ \\
\hline 61 & $\mathrm{R}_{51}$ & $\mathrm{R}_{47}$ & 80 & $\mathrm{R}_{68}$ & $\mathrm{R}_{65}$ \\
\hline
\end{tabular}

Table 8. Pick up current values of the Relays

\begin{tabular}{|c|c|c|c|c|c|}
\hline $\begin{array}{c}\text { Relay } \\
\text { number }\left(\mathrm{R}_{\mathrm{i}}\right)\end{array}$ & $\begin{array}{c}\text { Load } \\
\text { Current } \\
(\mathrm{amps})\end{array}$ & $\begin{array}{c}\text { Pick up } \\
\text { Current } \\
(\mathrm{amps})\end{array}$ & $\begin{array}{c}\text { Relay } \\
\text { number }\left(\mathrm{R}_{\mathrm{i}}\right)\end{array}$ & $\begin{array}{c}\text { Load } \\
\text { Current } \\
(\mathrm{amps})\end{array}$ & $\begin{array}{c}\text { Pick up } \\
\text { Current } \\
(\mathrm{amps})\end{array}$ \\
\hline 1 & 720 & 900 & 18 & 165 & 206 \\
\hline 2 & 716 & 895 & 19 & 133 & 166 \\
\hline 3 & 362 & 453 & 20 & 132 & 165 \\
\hline 4 & 363 & 454 & 21 & 136 & 170 \\
\hline 5 & 184 & 230 & 22 & 136 & 170 \\
\hline 6 & 185 & 231 & 23 & 317 & 396 \\
\hline 7 & 353 & 441 & 24 & 317 & 396 \\
\hline 8 & 352 & 440 & 25 & 132 & 165 \\
\hline 9 & 346 & 433 & 26 & 132 & 165 \\
\hline 10 & 345 & 431 & 27 & 29 & 36 \\
\hline 11 & 253 & 316 & 28 & 29 & 36 \\
\hline 12 & 253 & 316 & 29 & 66 & 83 \\
\hline 13 & 320 & 400 & 30 & 66 & 83 \\
\hline 14 & 319 & 399 & 31 & 105 & 131 \\
\hline 15 & 82 & 103 & 32 & 105 & 131 \\
\hline 16 & 87 & 109 & 33 & 48 & 60 \\
\hline 17 & 166 & 208 & 34 & 48 & 60 \\
\hline
\end{tabular}

From Table 7, it is found that relay $\mathrm{R}_{13}, \mathrm{R}_{14}, \mathrm{R}_{17}, \mathrm{R}_{25}, \mathrm{R}_{39}, \mathrm{R}_{43}, \mathrm{R}_{44}, \mathrm{R}_{50}, \mathrm{R}_{54}, \mathrm{R}_{58}$ are having two backups. So, they are having better protection reliability compare to other relays in present in the network. $R_{9}$ is having three backups. So it is having best protection reliability among all the relays present in the power network. One more significant observation from the table is $R_{56}$ 
is having no separate back up. Because it is connected to an isolated branch connecting branch 25-26. In such case, $R_{55}$, second and third zone will act as a backup for $R_{56}$. $R_{58}$ can be observed by second zone of $\mathrm{R}_{57}$ also. $\mathrm{R}_{54}$ can be observed by $\mathrm{R}_{58}$ or $\mathrm{R}_{56}$. The information regarding pick up current settings are shown in Table 8 . The value of pick up current of each over current relay is assumed roughly 1.25 times of the relevant maximum load in approximated integer form. The short circuit current data are shown in Table 9.

Table 8. Pick up current values of the Relays (Contd.)

\begin{tabular}{|c|c|c|c|c|c|}
\hline $\begin{array}{c}\text { Relay } \\
\text { number }\left(\mathrm{R}_{\mathrm{i}}\right)\end{array}$ & $\begin{array}{c}\text { Load Current } \\
(\mathrm{amps})\end{array}$ & $\begin{array}{c}\text { Pick up Current } \\
(\mathrm{amps})\end{array}$ & $\begin{array}{c}\text { Relay } \\
\text { number }\left(\mathrm{R}_{\mathrm{i}}\right)\end{array}$ & $\begin{array}{c}\text { Load Current } \\
(\mathrm{amps})\end{array}$ & $\begin{array}{c}\text { Pick up Current } \\
(\mathrm{amps})\end{array}$ \\
\hline 35 & 124 & 155 & 52 & 37 & 46 \\
\hline 36 & 124 & 155 & 53 & 40 & 50 \\
\hline 37 & 163 & 204 & 54 & 40 & 50 \\
\hline 38 & 163 & 204 & 55 & 73 & 91 \\
\hline 39 & 116 & 145 & 56 & 73 & 91 \\
\hline 40 & 116 & 145 & 57 & 82 & 103 \\
\hline 41 & 313 & 391 & 58 & 82 & 103 \\
\hline 42 & 313 & 391 & 59 & 110 & 138 \\
\hline 43 & 149 & 186 & 60 & 110 & 138 \\
\hline 44 & 149 & 186 & 61 & 125 & 156 \\
\hline 45 & 39 & 49 & 62 & 125 & 156 \\
\hline 46 & 39 & 49 & 63 & 65 & 81 \\
\hline 47 & 98 & 123 & 64 & 65 & 81 \\
\hline 48 & 98 & 123 & 65 & 3 & 4 \\
\hline 49 & 110 & 138 & 66 & 17 & 21 \\
\hline 50 & 110 & 138 & 67 & 81 & 101 \\
\hline 51 & 37 & 46 & 68 & 81 & 101 \\
\hline
\end{tabular}

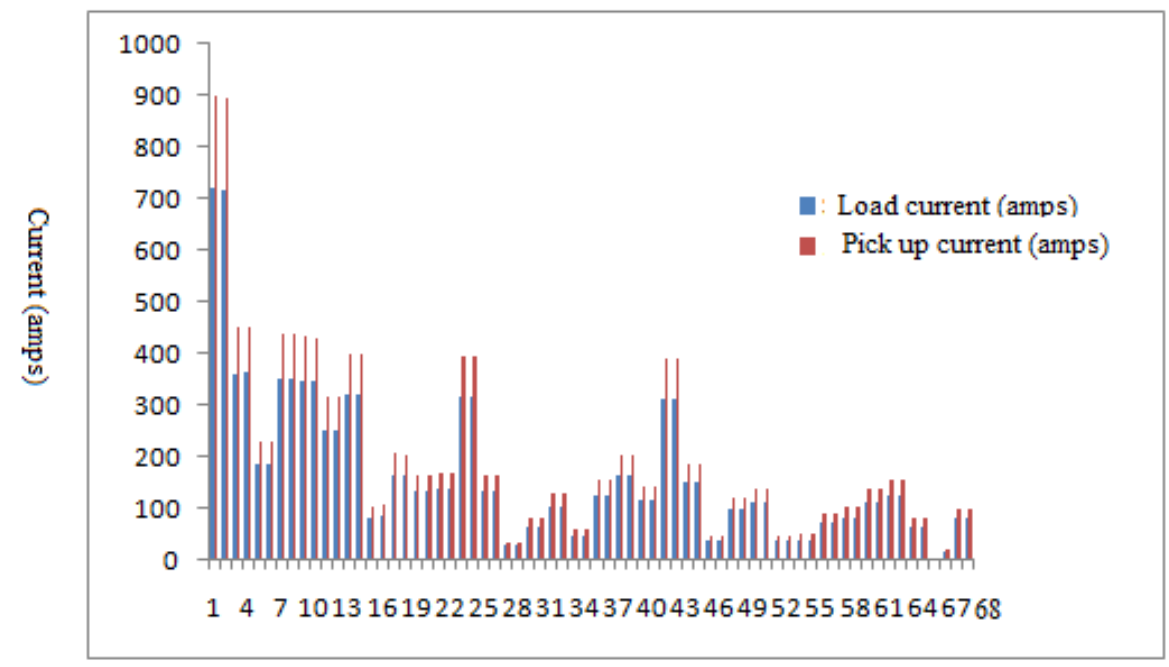

Relay numbers

Figure 10. Comparison of Load currents and pick up currents of Various relays 
Saptarshi ROY, et al.

Table 9. Short Circuit Current data for main and backup relays

\begin{tabular}{|c|c|c|c|}
\hline $\begin{array}{c}\text { Main } \\
\text { Relay }\left(\mathrm{R}_{\mathrm{i}}\right)\end{array}$ & $\begin{array}{c}\text { Back up } \\
\operatorname{Relay}\left(\mathrm{R}_{\mathrm{i}}\right)\end{array}$ & $\begin{array}{l}\text { Main relay } \\
\text { short circuit } \\
\text { current } \\
\text { ( amps) }\end{array}$ & $\begin{array}{l}\text { Back up } \\
\text { relay short } \\
\text { circuit } \\
\text { current(amps) }\end{array}$ \\
\hline 1 & 4 & 1270 & 522 \\
\hline 2 & 10 & 1929 & 421 \\
\hline 3 & 2 & 1869 & 1296 \\
\hline 4 & 8 & 1536 & 1536 \\
\hline 5 & 10 & 2134 & 436 \\
\hline 6 & 14 & 1959 & 1219 \\
\hline 7 & 3 & 723 & 718 \\
\hline 8 & 14 & 2045 & 1232 \\
\hline 9 & 1 & 2140 & 915 \\
\hline 9 & 12 & 2140 & 458 \\
\hline 9 & 6 & 2140 & 385 \\
\hline 10 & 16 & 1279 & 736 \\
\hline 11 & 10 & 2078 & 435 \\
\hline 12 & 18 & 2138 & 404 \\
\hline 13 & 7 & 1283 & 530 \\
\hline 13 & 5 & 1283 & 513 \\
\hline 14 & 18 & 1856 & 411 \\
\hline 14 & 11 & 1856 & 492 \\
\hline 15 & 9 & 1334 & 817 \\
\hline 16 & 17 & 1347 & 1343 \\
\hline 17 & 13 & 2194 & 806 \\
\hline 17 & 11 & 2194 & 492 \\
\hline 18 & 15 & 744 & 744 \\
\hline 19 & 68 & 2158 & 115 \\
\hline 20 & 66 & 825 & 257 \\
\hline 21 & 26 & 1689 & 269 \\
\hline 22 & 28 & 496 & 239 \\
\hline 23 & 26 & 1523 & 269 \\
\hline 24 & 32 & 684 & 244 \\
\hline 25 & 22 & 1484 & 60 \\
\hline 25 & 24 & 1484 & 235 \\
\hline 26 & 30 & 594 & 594 \\
\hline 27 & 21 & 633 & 633 \\
\hline 28 & 48 & 1257 & 244 \\
\hline 29 & 25 & 731 & 731 \\
\hline 30 & 39 & 1065 & 1065 \\
\hline 31 & 23 & 1210 & 774 \\
\hline 32 & 34 & 475 & 475 \\
\hline 33 & 31 & 633 & 633 \\
\hline 34 & 36 & 654 & 654 \\
\hline 35 & 33 & 466 & 466 \\
\hline 36 & 37 & 787 & 787 \\
\hline 37 & 40 & 1612 & 274 \\
\hline 38 & 35 & 1608 & 163 \\
\hline 39 & 44 & 1501 & 84 \\
\hline 39 & 38 & 1501 & 158 \\
\hline
\end{tabular}


Intelligent Coordination of Overcurrent and Distance Relays

\begin{tabular}{|c|c|c|c|}
\hline $\begin{array}{c}\text { Main } \\
\text { Relay }\left(\mathrm{R}_{\mathrm{i}}\right)\end{array}$ & $\begin{array}{c}\text { Back up } \\
\text { Relay }\left(R_{i}\right)\end{array}$ & $\begin{array}{c}\text { Main relay } \\
\text { short circuit } \\
\text { current } \\
(\text { amps })\end{array}$ & $\begin{array}{c}\text { Back up } \\
\text { relay short } \\
\text { circuit } \\
\text { current(amps) }\end{array}$ \\
\hline 40 & 29 & 415 & 415 \\
\hline 41 & 44 & 1648 & 80 \\
\hline 42 & 46 & 915 & 624 \\
\hline 43 & 40 & 1681 & 274 \\
\hline 43 & 42 & 1681 & 118 \\
\hline 44 & 50 & 1031 & 308 \\
\hline 44 & 45 & 1031 & 727 \\
\hline 45 & 41 & 911 & 911 \\
\hline 46 & 43 & 789 & 483 \\
\hline 47 & 27 & 1215 & 197 \\
\hline 48 & 52 & 449 & 449 \\
\hline 49 & 43 & 1215 & 481 \\
\hline 50 & 54 & 590 & 248 \\
\hline 50 & 51 & 590 & 342 \\
\hline 51 & 47 & 664 & 664 \\
\hline 52 & 49 & 898 & 650 \\
\hline 53 & 49 & 988 & 650 \\
\hline 54 & 58 & 449 & 449 \\
\hline 54 & 56 & 449 & 0.068 \\
\hline 55 & 58 & 924 & 449 \\
\hline 56 & $\begin{array}{c}55^{2 \text { nd } \& 3 r d} \\
\text { zone }\end{array}$ & 0.35 & 0.35 \\
\hline 57 & 53 & 481 & 481 \\
\hline 58 & 62 & 654 & 0.098 \\
\hline 58 & 60 & 654 & 7 \\
\hline 59 & 62 & 975 & 3 \\
\hline 60 & 64 & 158 & 158 \\
\hline 61 & 60 & 971 & 5 \\
\hline 62 & 63 & 214 & 214 \\
\hline 63 & 59 & 406 & 406 \\
\hline 64 & 61 & 309 & 309 \\
\hline 65 & 19 & 2040 & 1505 \\
\hline 66 & 67 & 1617 & 1497 \\
\hline 67 & 20 & 2489 & 488 \\
\hline 68 & 65 & 565 & 442 \\
\hline
\end{tabular}




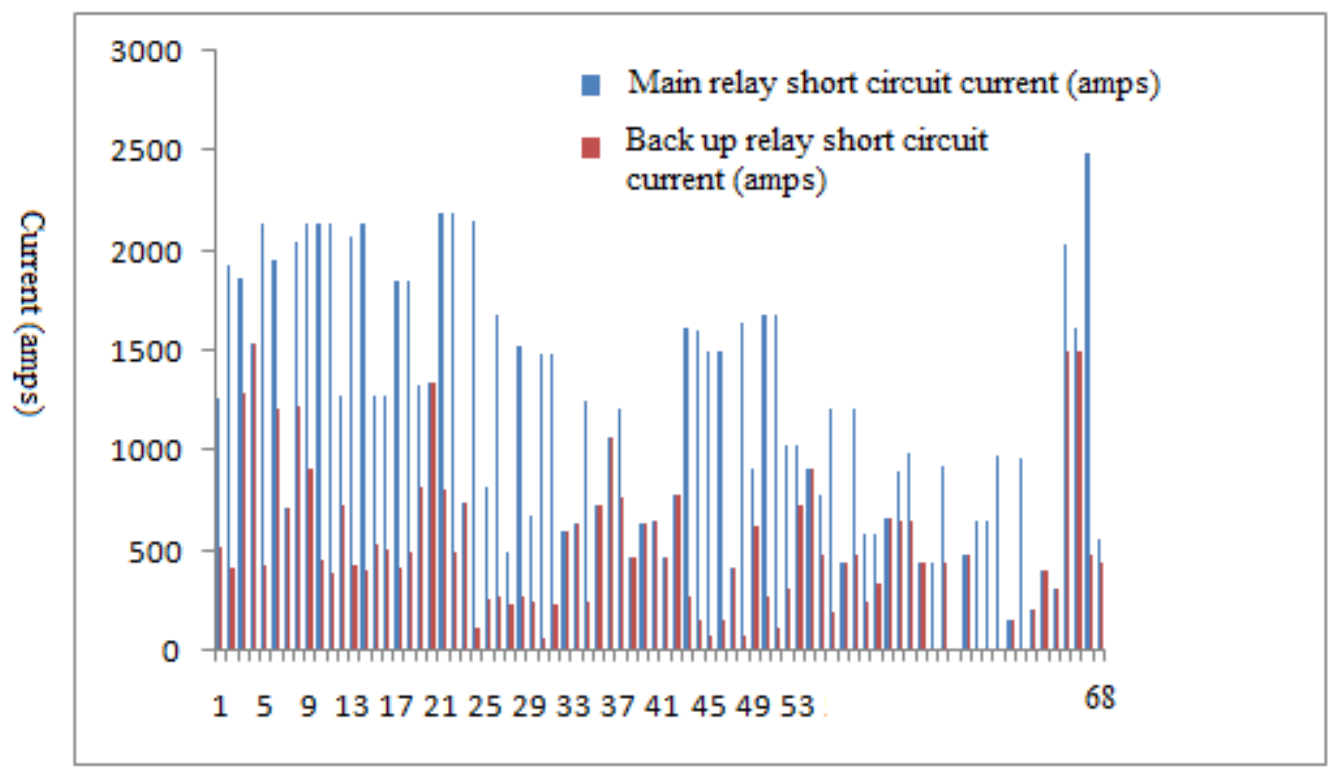

\section{Relay numbers}

Figure 11. Comparison of short circuit currents of main and backup relays for IEEE 30 bus system

The outputs are shown in Table 10 .

Table 10. Output Table (IEEE 30 bus system)

\begin{tabular}{|c|c|c|c|}
\hline Relay $\left(\mathrm{R}_{\mathrm{i}}\right)$ & $\begin{array}{c}\text { Second Zone } \\
\text { operation time (for } \\
\text { distance } \\
\text { relay) }\left(\mathrm{T}_{\mathrm{z} 2}\right)(\mathrm{sec})\end{array}$ & $\begin{array}{l}\text { TSM } \\
\text { (for over } \\
\text { current } \\
\text { relay) }\end{array}$ & $\begin{array}{c}\text { No. of } \\
\text { selected } \\
\text { Characteristic from } \\
\text { Table } 1\end{array}$ \\
\hline 1 & 0.989 & 0.05 & 7 \\
\hline 2 & 0.5479 & 0.1126 & 2 \\
\hline 3 & 0.3993 & 0.09245 & 3 \\
\hline 4 & 0.4499 & 0.07943 & 3 \\
\hline 5 & 0.4501 & 0.1465 & 2 \\
\hline 6 & 0.2828 & 0.15672 & 3 \\
\hline 7 & 0.581 & 0.05 & 7 \\
\hline 8 & 0.3897 & 0.10035 & 4 \\
\hline 9 & 0.3562 & 0.1043 & 4 \\
\hline 10 & 0.2988 & 0.0885 & 8 \\
\hline 11 & 0.3305 & 0.1234 & 3 \\
\hline 12 & 0.2889 & 0.1399 & 3 \\
\hline 13 & 0.4501 & 0.076 & 2 \\
\hline 14 & 0.3706 & 0.10025 & 3 \\
\hline 15 & 0.45 & 0.169 & 2 \\
\hline 16 & 0.5016 & 0.1854 & 2 \\
\hline 17 & 0.4929 & 0.17 & 2 \\
\hline 18 & 0.4327 & 0.0837 & 3 \\
\hline 19 & 0.4503 & 0.1693 & 2 \\
\hline 20 & 0.3503 & 0.1051 & 4 \\
\hline 21 & 0.45 & 0.151 & 2 \\
\hline 22 & 0.2609 & 0.0695 & 8 \\
\hline 23 & 0.4165 & 0.0878 & 3 \\
\hline 24 & 0.349 & 0.05 & 7 \\
\hline
\end{tabular}




\begin{tabular}{|c|c|c|c|}
\hline Relay $\left(\mathrm{R}_{\mathrm{i}}\right)$ & $\begin{array}{c}\text { Second Zone } \\
\text { operation time (for } \\
\text { distance } \\
\text { relay) }\left(\mathrm{T}_{\mathrm{z} 2}\right)(\mathrm{sec})\end{array}$ & $\begin{array}{l}\text { TSM } \\
\text { (for over } \\
\text { current } \\
\text { relay) }\end{array}$ & $\begin{array}{c}\text { No. of } \\
\text { selected } \\
\text { Characteristic from } \\
\text { Table } 1\end{array}$ \\
\hline 25 & 0.456 & 0.1453 & 2 \\
\hline 26 & 0.4336 & 0.0835 & 3 \\
\hline 27 & 0.3645 & 0.05 & 5 \\
\hline 28 & 0.4501 & 0.2368 & 2 \\
\hline 29 & 0.2514 & 0.1454 & 3 \\
\hline 30 & 0.3616 & 0.1683 & 7 \\
\hline 31 & 0.45 & 0.12994 & 2 \\
\hline 32 & 0.4313 & 0.0839 & 3 \\
\hline 33 & 0.4501 & 0.1551 & 2 \\
\hline 34 & 0.4932 & 0.3617 & 3 \\
\hline 35 & 0.2508 & 0.0715 & 8 \\
\hline 36 & 0.3429 & 0.1062 & 4 \\
\hline 37 & 0.2654 & 0.1357 & 3 \\
\hline 38 & 0.2658 & 0.1355 & 3 \\
\hline 39 & 0.45 & 0.1538 & 2 \\
\hline 40 & 0.6997 & 0.1064 & 2 \\
\hline 41 & 0.2942 & 0.1631 & 8 \\
\hline 42 & 0.2684 & 0.0551 & 7 \\
\hline 43 & 0.4613 & 0.1484 & 2 \\
\hline 44 & 0.4501 & 0.1121 & 2 \\
\hline 45 & 0.45 & 0.1935 & 2 \\
\hline 46 & 0.4519 & 0.1844 & 2 \\
\hline 47 & 0.4503 & 0.1508 & 2 \\
\hline 48 & 0.4294 & 0.0843 & 3 \\
\hline 49 & 0.2938 & 0.281 & 4 \\
\hline 50 & 0.3904 & 0.09473 & 3 \\
\hline 51 & 0.2767 & 0.6237 & 1 \\
\hline 52 & 0.4043 & 0.0624 & 5 \\
\hline 53 & 0.2688 & 0.3735 & 3 \\
\hline 54 & 0.45 & 0.1443 & 2 \\
\hline 55 & 0.4527 & 0.1535 & 2 \\
\hline 56 & 0.4502 & 0.05 & 2 \\
\hline 57 & 0.494 & 0.1343 & 3 \\
\hline 58 & 0.2539 & 0.1248 & 4 \\
\hline 59 & 0.2867 & 0.1288 & 3 \\
\hline 60 & 0.4605 & 0.05 & 1 \\
\hline 61 & 0.2677 & 0.1197 & 3 \\
\hline 62 & 0.4523 & 0.05 & 2 \\
\hline 63 & 0.3492 & 0.1053 & 4 \\
\hline 64 & 0.433 & 0.09029 & 3 \\
\hline 65 & 0.45 & 0.4269 & 2 \\
\hline 66 & 0.45 & 0.2918 & 2 \\
\hline 67 & 0.45 & 0.2127 & 2 \\
\hline 68 & 0.2971 & 0.1125 & 4 \\
\hline $\begin{array}{c}\text { Average } \\
\text { Value }\end{array}$ & 0.406504 & 0.141944 & - \\
\hline $\begin{array}{c}\text { Fitness } \\
\text { Value }\end{array}$ & 490.697 & - & - \\
\hline
\end{tabular}




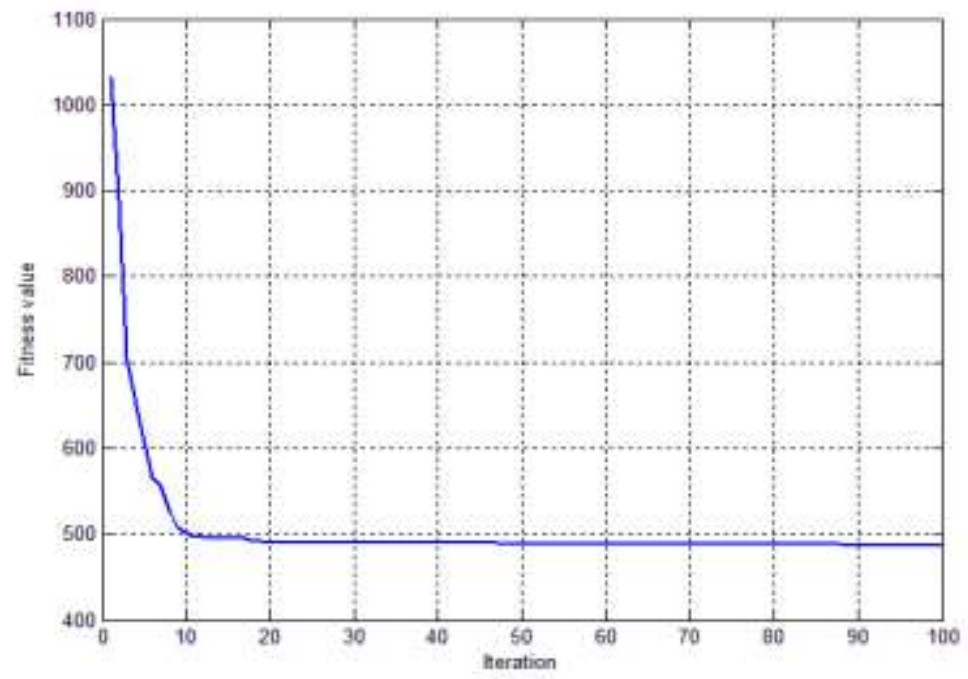

Figure 12. Convergence characteristics of the TLBO algorithm for IEEE 30 bus system

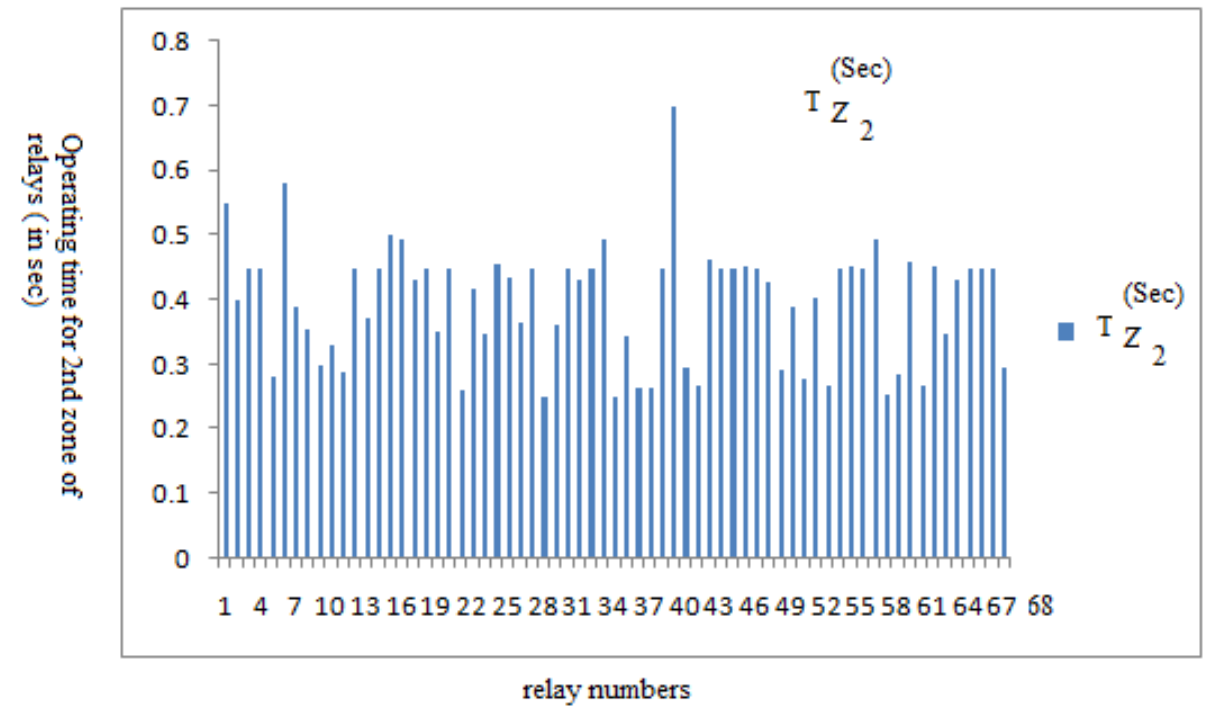

Figure 13. Comparison of operating time of second zone of relays for IEEE 30 bus system

From Table 8 and Table 10, it is observed that in case of relays with less pick up current, Characteristic 2 (Standard Inverse) is more suitable. Figure 10 to Figure 14 shows various outputs obtained from the test case for IEEE 30 bus system. 


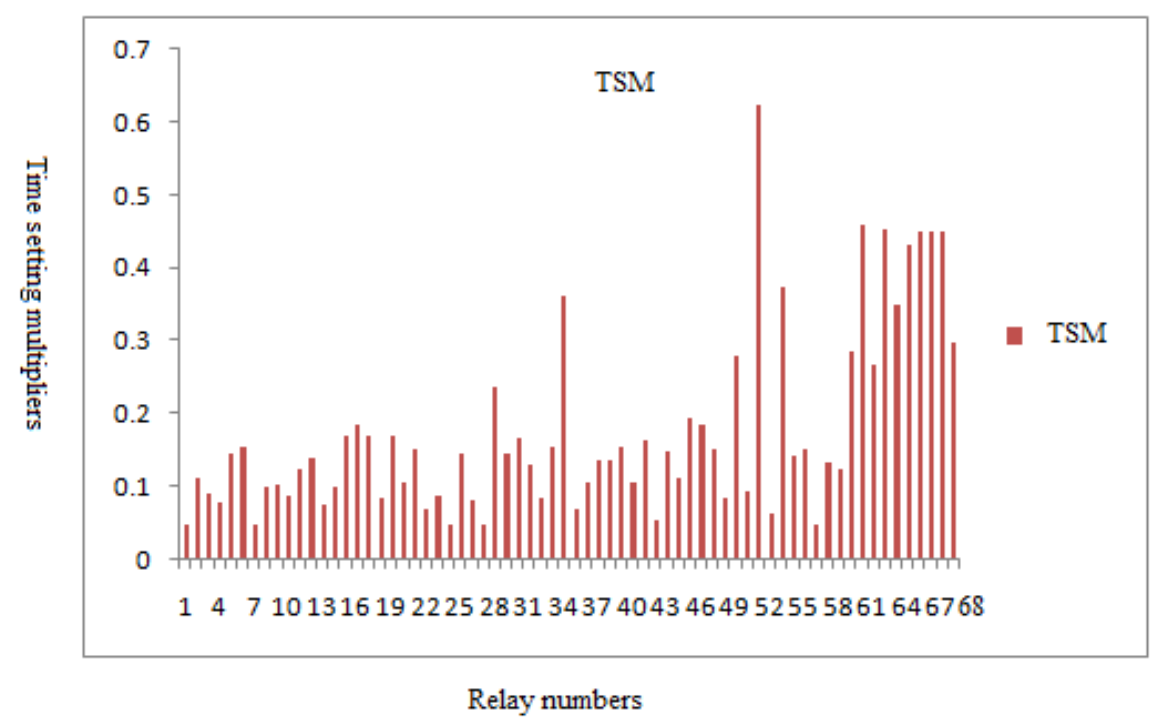

Figure 14. Comparison of optimum Time setting multipliers of relays for IEEE 30 bus system

Justification on incorporating different intelligent overcurrent relay characteristics: From Table 10, it is found that the TLBO applied to the test system used very frequently no. 2 intelligent characteristics. The reason can be justified as: the selection of types of characteristics depends on several factors. e.g-Short circuit data, load and pick up current data, fault location, type of fault etc. Here, in this particular case, no. 2 (Standard inverse) characteristics is frequently used. But the other characteristics also have equal importance when the types of faults or location or size of the test system (specially higher order test system) will change[37].

\section{Advantages of this Technique}

The discussed method is superior than previous methods used, in many respects. Firstly, the method is simple and reliable. Secondly, the method is capable of reducing mis-coordination chances. Thirdly, the method is capable to handle both discrete and continuous time setting multiplier (TSM) cases. Fourthly, the method uses the different intelligent over current relay characteristics available in digital relays to reduce the time of operation. The algorithm is finding the minimum optimum value of relay operation satisfying all the constraints optimally from a look up table created in the memory during execution using the intelligent characteristics. Fifthly, the problem is converging very fast and in least CPU elapsed time than other methods. From our work we have shown, both in case of a small and a big test system, the problem is converging in less than 20 iterations by using this method and in least CPU elapsed time (ref. Table 12 and Table 13). Thus it is saving computational time, as well as the memory requirements needed for the program. The comparison of performance of this algorithm with contemporary other techniques like GA, PSO is shown in Subsection 7.2.

\section{Discussions}

\section{A. Minimization of the number of relays}

The complexity of the co-ordination problem increases in multiple loop system which share some relays. Hence we have to find one common acceptable setting for relays, which share multiple loops, so, that their co-ordination in individual loops is achievable. The number of such relays should be kept to minimum, so that we make minimum assumptions on relay settings in co-ordination of loops. Such relays are called minimum break point relays. There can be multiple choices to minimum break point relays. In this subsection we will concentrate on computation of minimum break point set of relays based on critical element finding and network graph theory[26]-[30]. 


\section{Procedure}

For obtaining minimum break point set of relays, we follow a technique, which is the combination of simulation and by using network graph theory. The procedure is as follows:

i)Finding critical element of the network

Critical elements are such elements of a network (bus, transmission line), which if removed, the complete network will be suffering from blackout. Specially in case of big systems, its effect is huge. Such critical elements should be always protected by relays. The critical elements obtained from power world simulation are as follows for the used test systems in the work. Table 11 shows critical elements of IEEE 5 bus and IEEE 30bus system.

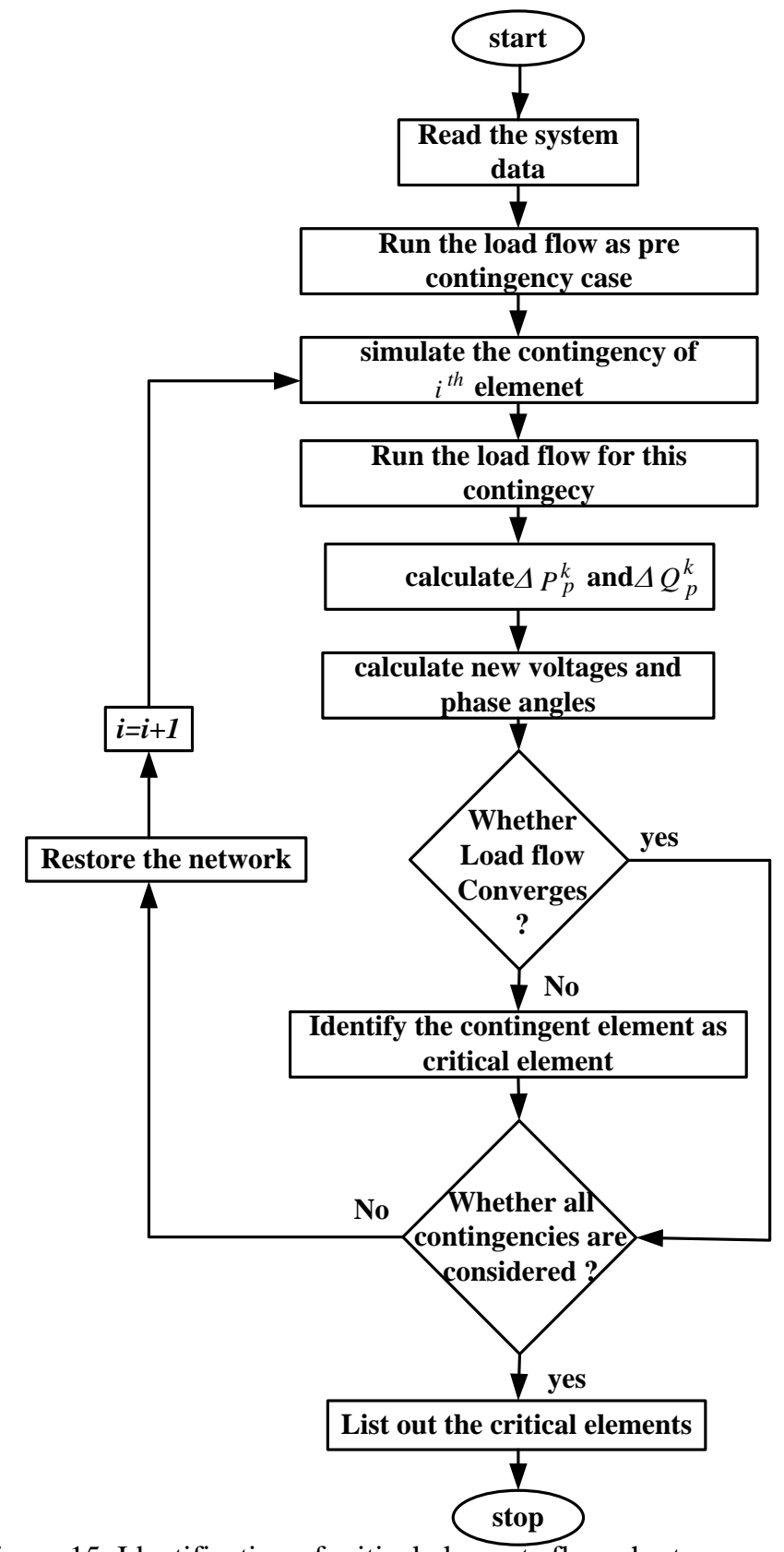

Figure 15. Identification of critical elements flow chart 
Figure 15 shows identification of critical elements of a power network flow chart.

$\mathrm{Pp}^{\mathrm{K}}$ and $\mathrm{QP}^{\mathrm{K}}$ denotes active and reactive power of $\mathrm{K}^{\text {th }}$ bus of the system.

Table 11. Critical Elements of Network

\begin{tabular}{|c|c|c|}
\hline Test system & Critical buses & Critical lines \\
\hline IEEE 5-bus & - & - \\
\hline IEEE 30-bus & 2,6 & $1-2$ \\
\hline
\end{tabular}

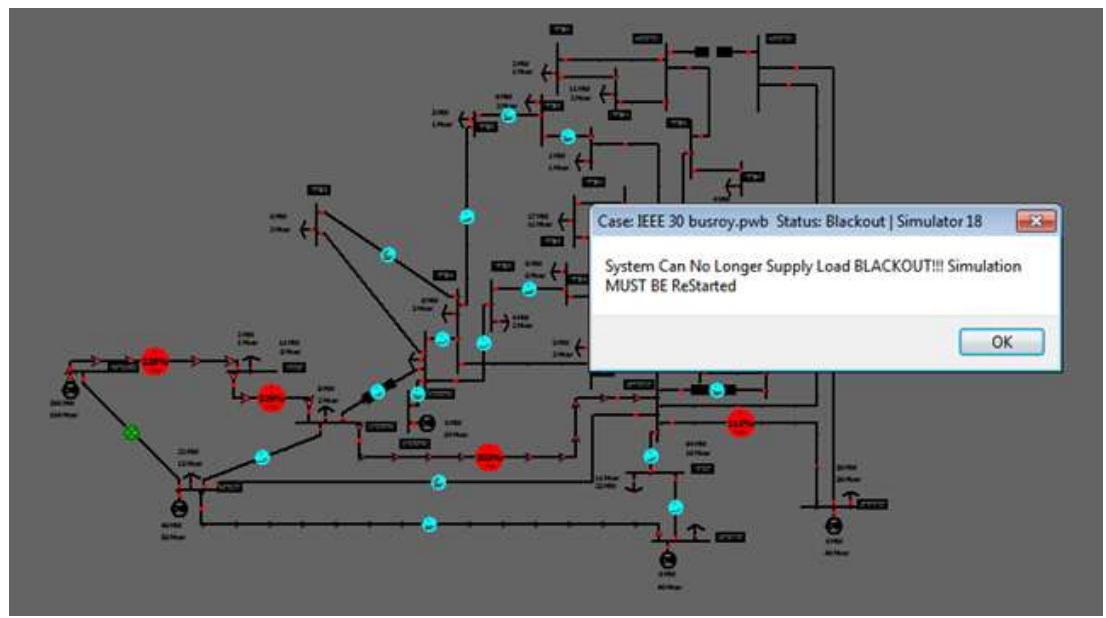

Figure 16. Power World Simulation of IEEE 30-bus when critical line 1-2 is under contingency

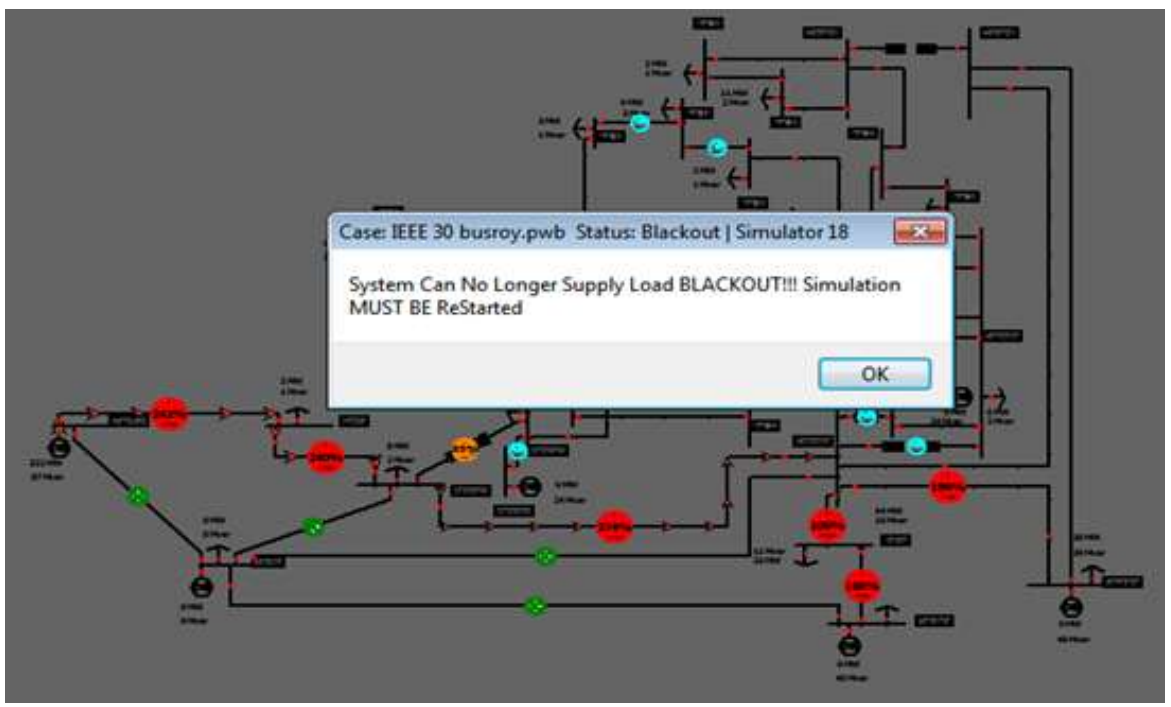

Figure 17. Power World Simulation of IEEE 30-bus when critical bus 2 is under contingency 


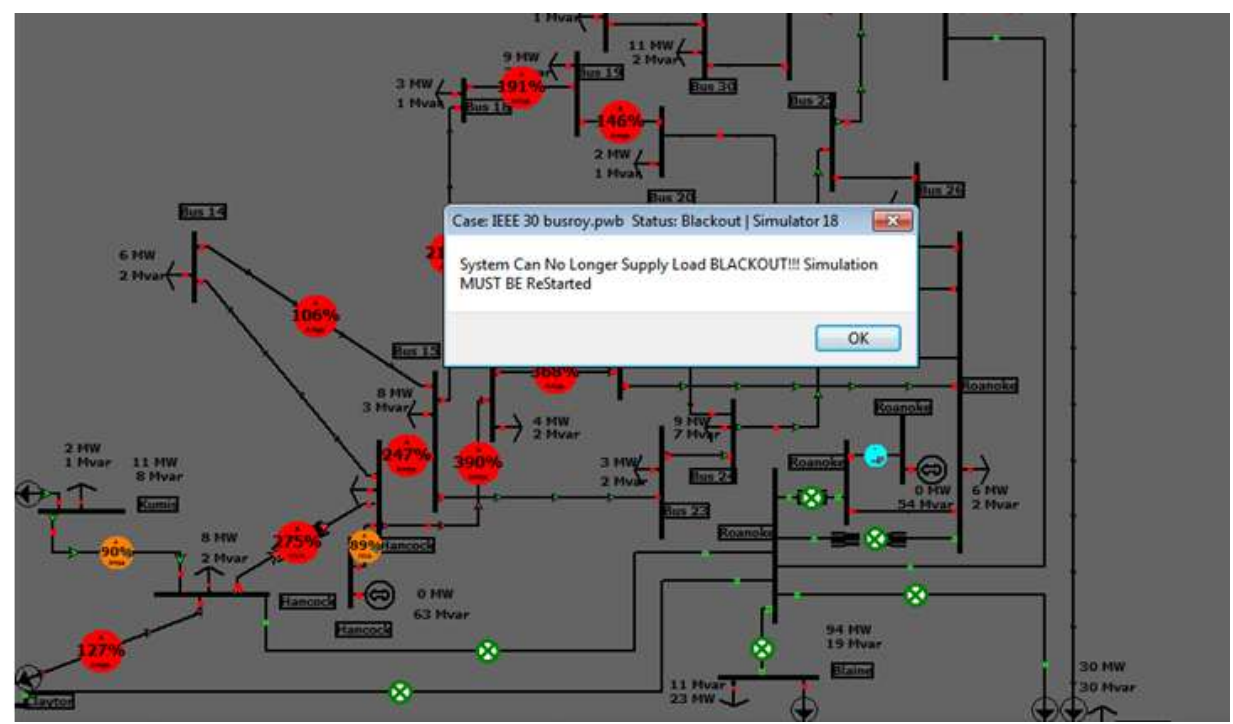

Figure 18. Power World Simulation of IEEE 30-bus when critical bus 6 is under contingency

Figure 16, Figure 17 and Figure 18 shows the simulation when the critical elements of IEEE 30 bus system are under contingency.

\section{ii) Apply network graph theory}

For rest of the network, the Minimum break point set relays can be determined from LU factorization of reduced and permuted incidence matrix. L-matix indicates minimum break point sets [30]-[35]. Table 12, shows the minimum break point set obtained for the test systems. Here one thing is needed to be mentioned that, a network may have multiple minimum break point set solutions. Here we have shown just one possible solution for minimum break point set.

Table 12. Minimum break point set of the network

\begin{tabular}{|c|c|}
\hline IEEE Test system & $\begin{array}{c}\text { Minimum break point set } \\
\text { Relay no. }\left(\mathrm{R}_{\mathrm{i}}\right)\end{array}$ \\
\hline IEEE 5 bus & $2,3,6,7,9,12,14$ \\
\hline IEEE 30 bus & $1,6,8,9,11,12,14,17,19,23,27,37$, \\
& $39,41,46,49,52,59,64,65,67$ \\
\hline
\end{tabular}

\section{B. Comparative study with GA and PSO}

TLBO does not use any algorithm specific control parameter for finding global optimum solution. This property of this algorithm is an huge advantage over contemporary other optimization techniques. GA (Genetic algorithm) uses Selection rate, mutation rate and cross over rate. PSO (Particle Swarm Optimization) uses inertia weight, social and cognitive parameters. The proper tuning of these parameters are very important for the performance of these optimization algorithms. TLBO does not need such kind of parameters. It only need population size and number of generations for working. So, TLBO becomes highly consistent optimization algorithm. It converges very fast and superior compare to GA and PSO. Table 13 and 14 lists the comparison study among TLBO, GA and PSO results for both the test systems. Figure 19 and Figure 20 shows the convergence curve for IEEE 5 bus system with GA and PSO. 
Table 13. Comparative study with GA and PSO (IEEE 5 bus)

\begin{tabular}{|l|c|c|c|}
\hline Attributes & TLBO & GA & PSO \\
\hline Number of iterations to converge & 17 & 10 & 24 \\
\hline Average time per iteration (Sec) taken & 0.0038 & 0.013 & 0.0063 \\
\hline $\begin{array}{l}\text { Total time taken to converge (CPU elapsed time) } \\
\text { (sec) }\end{array}$ & 0.0646 & 0.13 & 0.1512 \\
\hline
\end{tabular}

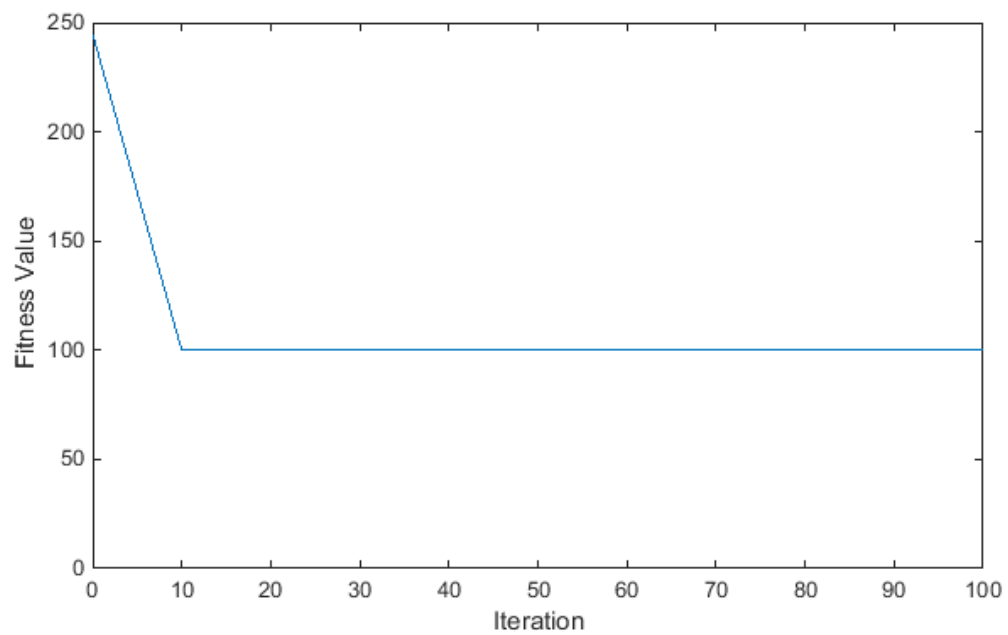

Figure 19. Convergence characteristics using GA (IEEE 5 bus)

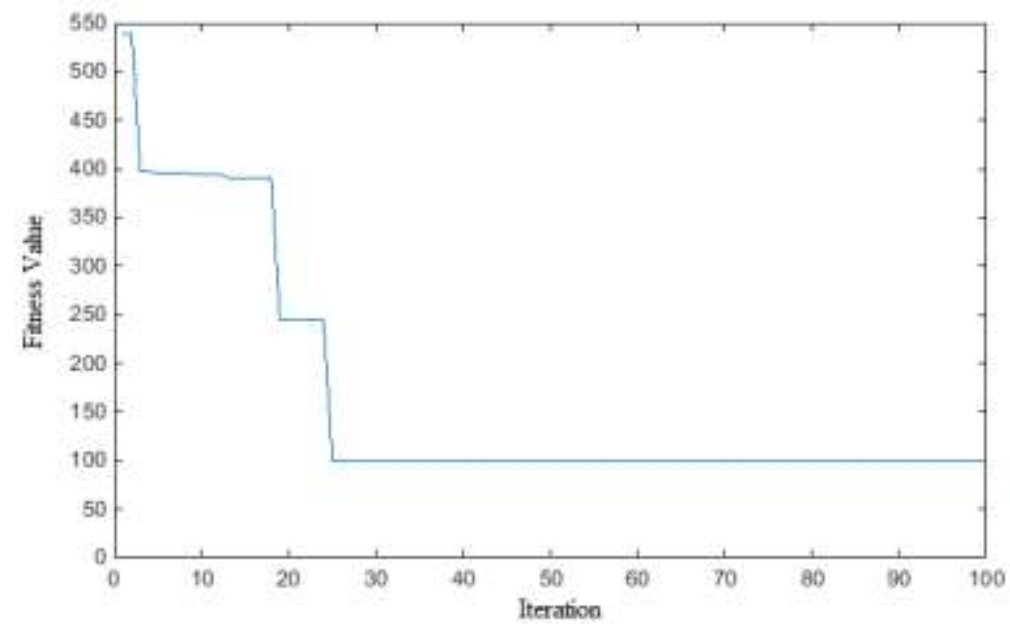

Figure 20. Convergence characteristics using PSO (IEEE 5 bus)

Table 14. Comparative study with GA and PSO (IEEE 30 bus)

\begin{tabular}{|l|c|c|c|}
\hline Attributes & TLBO & GA & PSO \\
\hline Number of iterations to converge & 20 & 20 & 19 \\
\hline Average time per iteration (Sec) taken & 0.0138 & 0.0144 & 0.016 \\
\hline $\begin{array}{l}\text { Total time taken to converge (CPU elapsed time) } \\
\text { (sec) }\end{array}$ & 0.276 & 0.288 & 0.304 \\
\hline
\end{tabular}

From both the tables, it is seen TLBO is faster than other contemporary algorithms like GA and PSO with respect to process speed (CPU elapsed time). With respect to increase in test 
system's size, the convergence time also increases. Figure 21 and Figure 22 shows the convergence curve for IEEE 30 bus system with GA and PSO.

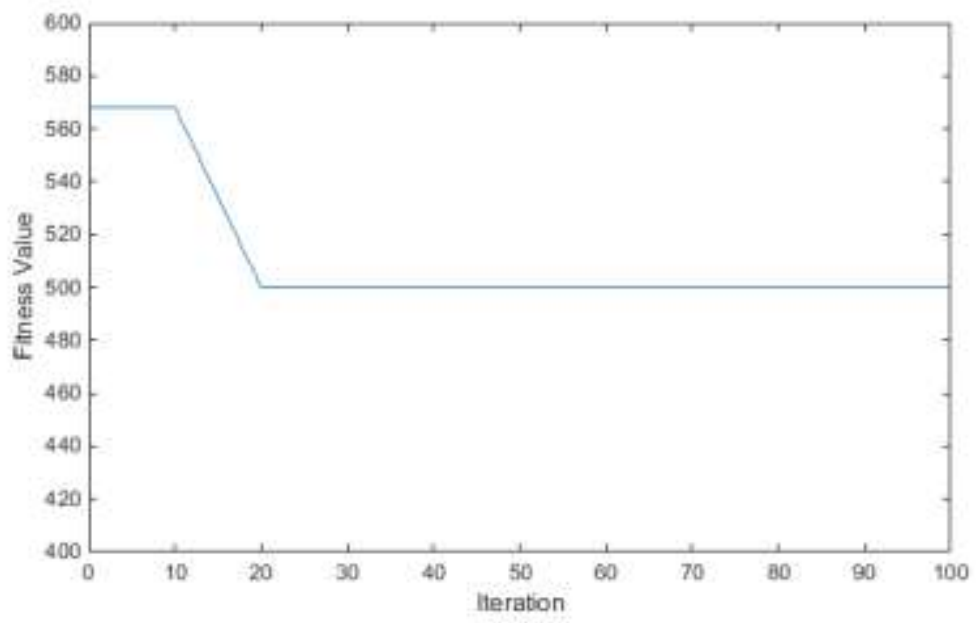

Figure 21. Convergence characteristics using GA (IEEE 30 bus)

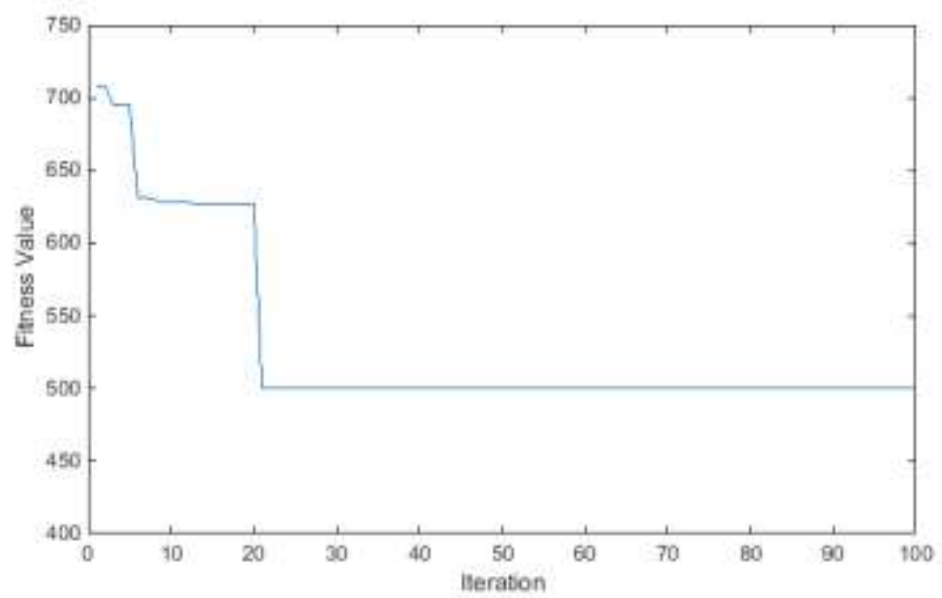

Figure 22. Convergence characteristics using PSO (IEEE 30 bus)

Here the simulation is done on a Dell Laptop, processor: Intel ${ }^{\circledR}$ core (TM) i3-2350 M CPU@2.30 GHZ, RAM: 8.00 GB, Simulator: MATLAB R 2014b.

\section{Conclusions}

This paper focused on optimal coordination of directional and over current relays. The problem statement and various constraints to be satisfied are already presented in the paper. Teaching learning based optimization (TLBO), which is a modern meta-heuristic technique is applied to solve the problem. The optimum time of operation, TSM, pick up currents of relays are calculated for an IEEE 5 bus system and IEEE 30 bus system. All the constraints are found within desirable range. Which intelligent over current characteristics are required to get the desired result are also selected. Coordination time interval is taken $0.25 \mathrm{sec}$ for each cases. The protection settings seems to be satisfactory for the discussed power networks as they are performing better compare to contemporary other meta-heuristic techniques like GA and PSO. Iteration time increases with the system size increases, although the number of iterations for 
convergence remains more or less the same irrespective of the size of the system. As a future scope of this work, relay coordination on higher and practical test systems can be implemented with distributed generation resources and dual settings for more protection reliability.

\section{Appendix}

The test system data are obtained from Ref.[24] and Ref.[25].

\section{References}

[1]. A.J Urdaneta, L.G Perez, and R Nadira, "Optimal co-ordination of directional overcurrent relays in interconnected power system”, IEEE Transactions on Power Delivery, Vol.3, No 3, pp.903-911, July 1988.

[2]. A.J Urdaneta, J Sanchez, J Fajardo and H Resterpo, "Coordination of directional over current relays timing using linear programming," IEEE Transactions on Power Delivery, Vol.11, No.1, pp.122-129, Jan 1996.

[3]. B Chattopadhyay, T.S Sidhu, and M.M.S Sachdev, "An on-line relay co-ordination algorithm for adaptive protection using linear programming techniques, IEEE Transactions on Power Delivery," Vol.11, No.1, pp.165-173, Jan 1996.

[4]. H.A Askarian and R Keyhani, "Optimal co-ordination of overcurrent relays in power system by dual simplex method," Presented at The Australasian Universities Power Engineering Conference, Perth, Australia ,1995.

[5]. C.W So, K.K Li, K.Y Fung, and K.T Lai, "Application of genetic algorithm for over current relay co-ordination," in proceedings of Instrumentation Electrical Engineering Conference Developments in Power System Protection, Mar. 25-27, 1997, pp. 66-69.

[6]. H Zeineldin, E El-Saadany, and M.A Salama, "Optimal co-ordination of over current relays using a modified particle swarm optimization," Electric Power System Research, Vol.76, No.11, pp.988-995, 2006.

[7]. C.W. So and K.K Li, "Time co-ordination method for power system protection by evolutionary algorithm," IEEE Transactions on Industrial Applications, Vol.36, No.5, pp.1235-1240, Sep/Oct 2000.

[8]. F. Razavi, H Torkaman, Abyaneh, A Al-Dabbagh, R Mohammadi, and H Askaria, "A new comprehensive genetic algorithm method for over current relays co-ordination," Electric Power System Research, Vol. 92, No. 9, 2008.

[9]. J. Sadeh, M Bashir and V Aminotojari, "Optimal co-ordination of over current and distance relays with hybrid genetic algorithm," in the proceedings of $10^{\text {th }}$ International conference on Environment and Electrical Engineering, IEEE, Rome, Italy, May 8-11,2011.

[10]. R.M Chabanloo, F Razavi, S.S.H Kamangar and H.A Abyanch, "Optimal combined overcurrent and distance relays co-ordination incorporating intelligent overcurrent relay characteristics selection," IEEE Transactions on Power Delivery, Vol.26, No.3, pp.13811391, July 2011.

[11]. M Singh, B.K Panigrahi and A.R Abhyankar, "Optimal co-ordination of directional overcurrent relays using teaching learning-based optimization (TLBO) algorithm," Electrical Power and Energy Systems, Vol.50, pp.33-41,2013.

[12]. A.A Kalage and N.D Ghawghawe, "Optimum co-ordination of directional overcurrent relays using modified adaptive teaching learning based optimization algorithm," Intelligent Industrial System, Vol.2, No.1, pp.55-71,2016.

[13]. D Saha, P Das, B.K Saha Roy and A Dutta, "Optimal co-ordination of DOCR in interconnected power systems," presented at the IEEE $2^{\text {nd }}$ International Conference on Control, Instrumentation, Energy and Communication, Jan 28-30, Kolkata, India, 2016.

[14]. R.V Rao and G.G Wagmare, "A comparative study of a teaching-learning-based optimization algorithm on multi-objective unconstrained and constrained functions," Journal of King Saud University-Computer and Information Sciences, Vol.26, pp.332-346, 2013. 
[15]. R.V Rao and V Patel, "An elitist teaching-learning-based optimization algorithm for solving complex constrained optimization problems," International Journal of Industrial Engineering Computations, Vol. 3, pp.535-560, 2012.

[16]. M Ojaghi and R Ghahremani, "Piece-wise linear characteristic for co-ordinating numerical over current relays," IEEE Transactions on Power Delivery, Vol.32, No.1, pp.145-151, Feb 2017.

[17]. R.V Rao, J Balic and V.V.J Savsani, "Teaching-learning-based optimization algorithm for unconstrained and constrained real-parameter optimization problems," Engineering Optimization, Vol.44, No.12, pp.1447-1462, 2012.

[18]. R.V Rao, "Review of applications of TLBO algorithm and a tutorial for beginners to solve the unconstrained and constrained optimization problems," Decision Science Letters, Vol. 5, No.1, pp.1-30,2016.

[19]. M.Y.Shih, L.Martirano, Z.Leonowick and A.Conde, "An adaptive overcurrent coordination scheme to improve relay sensitivity and overcome drawbacks due to distributed generation in smart grids," IEEE Transactions on Industry Applications, Vol. PP , Issue 99, June 2017.

[20]. J.He, D.Zhan, F.Ding, C.Li and L.Liu, "A new co-ordinated backup protection scheme for distribution network containing distributed generation," Protection and Control of Modern Power Systems, Springer, Vol.2,Issue 10 , March 2017.

[21]. P.N Korde and P.P.Bedekar, "Optimal overcurrent relay co-ordination in distribution system using nonlinear programming method," presented at the International Conference on Electrical Power and Energy Systems, IEEE , Dec 14-16, Bhopal, India,2016.

[22]. O.V.Gnana, Swasthika, B Roy, I Bose, S Kodgule and Dr.S.Hemamalini, "Optimization technique based adaptive overcurrent protection in microgrids," Journal of Electrical Systems, Special Issue AMPE 2015, pp.75-80, Dec 2015.

[23]. A. S Saidan, M.A.A Razak and, N.A Salim, "Particle swarm optimization based technique for optimal placement of overcurrent relay in power system," Journal of Electrical Systems, Special Issue AMPE 2015, pp.154-163, Dec 2015.

[24]. IEEE 5- bus system data, Online link available: http://shodhganga.inflibnet.ac.in/bitstream/10603/26549/14/14_appendix.pdf

[25]. Power flow data for IEEE 30 bus test case, University of British Columbia. Available: http://www.ece.ubc.ca/ hameda/download_files/case30.m

[26]. J.M.Tripathi, Adhishree and Ram Krishan, "Optimal coordination of overcurrent relays using gravitational search algorithm with DG penetration," Presented in $6^{\text {th }}$ IEEE Power India International Conference, 5-7 December, Delhi, India, 2014.

[27]. L.Huchel and H.H.Zeineldin, "Planning the coordination of directional overcurrent relays for distribution systems considering DG”, IEEE Transactions on Smart Grid, Vol. 7 , No. 3, pp.1642-1649, May 2016.

[28]. Y.Atles et al., "Adaptive protection scheme for a distribution system considering gridconnected and islanding modes of operation", Energies, Vol.9, Issue 5, article no. 378, doi:10.3390/en9050378

[29]. L.Huchel, H.H.Zeineldin and E.F.E Saadany, "Protection coordination index enhancement considering multiple DG locations using FCL", IEEE Transactions on Power Delivery, Vol.32, No.1, pp. 344-350, February 2017.

[30]. L.Liu and L.Fu, "Minimum breakpoint set determination for directional overcurrent relay coordination in large-scale power networks via matrix computations," IEEE Transactions on Power Delivery, Vol.32, No.4, pp.1784-1789, August 2017.

[31]. J.Moirangthem, S.S.Dash and R.Ramaswami, "Zero-one integer programming approach to determine the minimum break point set in multi-loop and parallel networks", Journal of Electrical Engineering and Technology, Vol. 7, No.2, pp.151-156, March 2012.

[32]. J.Moirangthem, S.S.Dash and R.Ramaswami, "Determination of minimum break point set using particle swarm optimization for system-wide protective relay setting and 
coordination, " European Transactions on Electrical Power, Vol.22, Issue 8, pp.11261135, November 2012.

[33]. D.Ye, J.Ma and Z.Wang, "A novel method for determining minimum break point set based on network reduction and relays incidence matrix," IEEE International Conference on Critical Infrastructure, Beijing, China, 20-22 September, 2010.

[34]. Q.Yue, W.Yu and F.Lu, "Gene evolution algorithm to determine minimum break point set for optimal coordination of directional protection relays in multiloops networks," IEEE Power Systems Conference and Exposition, New York, USA, 10-13 October, 2004

[35]. R.K.Gajbhiye, A.De and S.A.Soman, "Computation of Optimal Break Point Set of RelaysAn Integer Linear Programming Approach," IEEE Transactions on Power Delivery, Vol.22, No.4, pp. 2087-2098, October 2007

[36]. H.M.Sharaf, H.H.Zeineldin and E.E.Saadany, "Protection Coordination for Microgrids with Grid Connected and Islanded Capabilities using Communication Assisted Dual Setting Directional Overcurrent Relay," IEEE Transactions on Smart Grid, Vol.9, No.1, pp.143-151, January 2018.

[37]. Saptarshi Roy, Dr.P.Suresh Babu and N.V.Phanendra Babu, "Intelligent Overcurrent and Distance Relays Coordination: A Comparative Analysis using GA, PSO and TLBO," $4^{\text {th }}$ IEEE International Conference ICEES 2018, SSN College of Engineering, Tamilnadu, 79 February, 2018.

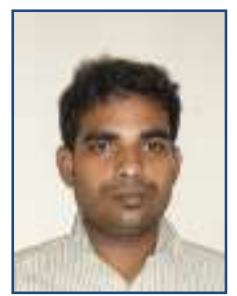

Saptarshi ROY Received the B.E degree in Electrical Engineering from Jadavpur University, West Bengal, India in 2009. Received M.Tech degree from NIT Warangal in 2014. Currently he is pursuing $\mathrm{PhD}$ in Electrical Engineering in the department of Electrical Engineering, National Institute of Technology, Warangal, India. His areas of interest are power system protection, Phasor Measurement Unit applications in power systems, Synchrophasors applications in power systems. He has published more than 15 research papers in National, International conferences and journals till now. He worked as reviewer in several IEEE conferences. He is a regular reviewer in IEEE Systems Journal.

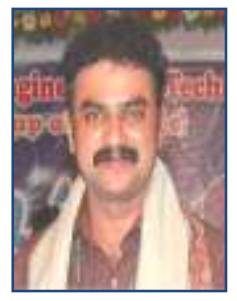

Suresh Babu PERLI Currently he is working as an Assistant Professor in Department of Electrical Engineering, National Institute of Technology, Warangal. His areas of interest are Power System Protection with digital multifunction relays, Development of Adaptive protection schemes and Digital filtering algorithms.

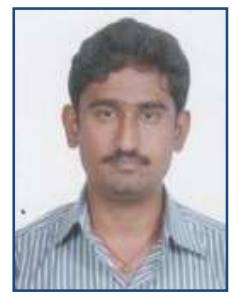

N V Phanendra BABU He is currently doing Research in the Department of Electrical Engineering, National Institute of Technology Warangal, India. His areas of interest are Optimal PMU Placement, Wide-Area protection. 